\title{
Revisiting firm flexibility and efficiency: evidence from the EU dairy processing industry
}

\section{Journal Article}

\section{Author(s):}

Hirsch, Stefan; Mishra, Ashok; Möhring, Niklas (D); Finger, Robert (1)

Publication date:

2020-07

Permanent link:

https://doi.org/10.3929/ethz-b-000330932

Rights / license:

In Copyright - Non-Commercial Use Permitted

Originally published in:

European Review of Agricultural Economics 47(3), https://doi.org/10.1093/erae/jbz003 


\section{Postprint}

This is the accepted version of a paper published in the European Review of Agricultural Economics. This paper has been peer-reviewed but does not include the final publisher proofcorrections or journal pagination.

\section{Citation for the original published paper:}

Hirsch, S., Mishra, A., Möhring, N., Finger, R. (2020). Revisiting Firm Flexibility and Efficiency: Evidence from the EU Dairy Processing Industry. European Review of Agricultural Economics 47(3): 971-1008

\section{https://doi.org/10.1093/erae/jbz003}

Access to the published version may require subscription.

N.B. When citing this work, cite the original published paper. 


\title{
Revisiting Firm Flexibility and Efficiency: Evidence from the EU Dairy Processing Industry
}

\begin{abstract}
We analyze the flexibility of EU dairy processors to adjust production to fluctuating economic conditions. For a set of 2,186 firms, we derive production flexibility measures representing the effect of output variations on costs. The results reveal that flexibility is highest in Poland and Italy and lowest in Spain. Several firm-specific factors such as size and age of the firm are found to affect firm flexibility. Moreover, we detect a tradeoff between flexibility and technical efficiency for large firms indicating that a sole focus on firm efficiency can be insufficient. Finally, the results show that during economic crisis flexibility can help to sustain profitability.
\end{abstract}

Keywords: Production flexibility; Flexibility-Efficiency tradeoff; Financial crisis; Dairy industry

JEL-codes: C23, C26, L23, L25, L66

\section{Introduction}

The ability to adjust to changing economic conditions is a crucial firm asset. Particularly production flexibility, i.e., firms ' capability to adapt output without significant increases in average costs, can be an important factor for firms`competitiveness in dynamic environments. From a theoretical perspective, Mills and Schumann (1985) extend the standard competitive equilibrium model with identical firms and stationary demand by allowing for technological diversity and demand fluctuations. A primary assumption of this approach is the co-existence of large and small firms caused by a tradeoff between (static) efficiency and flexibility (dynamic efficiency) (Stigler, 1939; Ghemawat and Ricart Costa, 1993). Within this framework, it is possible for smaller, less efficient firms with high average costs to survive if they are sufficiently flexible to absorb a disproportionate share of output fluctuations. In contrast, large, efficient firms with low average costs but lower flexibility can rely on output levels more stable than their industry as a whole (Mills and Schumann, 1985; Mills, 1985). This "theory of industry structure with fluctuating demand" has been empirically confirmed for a diverse set of sectors and countries ${ }^{1}$. While this approach solely focuses on the "tactical flexibility" of firms -i.e., the ability to adjust aggregate output over time-, von Ungern-Sternberg (1990) introduces

\footnotetext{
${ }^{1}$ See for example Mills and Schumann (1985), Fiegenbaum and Karnani (1991) and Das et al. (1993) for the US, Zimmermann (1995) for German manufacturing firms, and Weiss (2001) for the Austrian farm sector.
} 
the concept of "operational flexibility" related to the capacity to switch quickly between products (Weiss, 2001) ${ }^{2}$. Empirical evidence on the relationship between tactical and operational flexibility is mixed. For instance, Weiss (2001) reveals a negative interrelationship between tactical and operational flexibility because firms with a low capability to adjust their product mix to exogenous shocks are forced to adjust aggregate output instead. In contrast, Renner et al. (2014) show that product diversification can increase overall flexibility of the firm due to arising cost complementarities. De Toni and Tonchia (1998; 2005) classify the concept of flexibility from a broader perspective by additionally focusing on strategic flexibility of firms related to i) the number of strategic options available, ii) the speed of variation between competitive priorities, iii) the variety of possible new business units and iv) the ability to quickly move from one area of operations to another. In this context, Kortmann et al. (2014) show that mass customization capabilities (i.e., the capability to rapidly produce customized products at large volume, low cost, and high quality) and innovative activity balance the tradeoff between strategic flexibility and efficiency leading to sustainable competitive advantages for firms.

Earlier research on flexibility in the agribusiness sector either has provided theoretical evidence (e.g., Zeller and Robison, 1992) or has contributed empirically by focusing on the farm level (e.g., Weiss, 2001; Renner et al., 2014; Renner, 2014; Bokusheva and Čechura 2017). In the mid-1980s, Mills (1984) shows that, particularly in fluctuating industry environments such as the food processing industry, considering possible tradeoffs between tactical flexibility and efficiency in a firm`s management decisions can be crucial for achieving competitive advantages (Vokurka and O'Leary-Kelly, 2000). However, despite the relevance of flexibility for firms in the EU food processing industry no study has been conducted so far. We contribute to filling this gap and provide a comprehensive analysis of firm flexibility in four leading EU dairy processing sectors that reflect the large gradient concerning geographical location, production technologies, and market structures within the EU (Wijnands et al. 2007): France, Italy, Poland, and Spain.

The EU dairy processing sector is characterized by high saturation, strong downstream bargaining power, fluctuating input prices, and increasingly sophisticated consumer demands implying that associated firms continuously have to adjust their production (Chavas et al., 2010; Banterle et al., 2013; Hirsch and Gschwandtner, 2013). Thus, firms in the dairy processing sector frequently need to adapt, which implies that production flexibility can be an essential firm characteristic in this industry. For example, the EU food sector has recently been impacted

\footnotetext{
${ }^{2}$ For overviews of the concepts used to measure flexibility in the management literature we refer to Sethi and Sethi (1990), Gupta and Somers (1992), De Toni and Tonchia (1998, 2005) and Jain et al. (2013).
} 
by several events. These include the end of the EU milk quota system, a reduction of intervention prices for butter and skimmed milk powder, rapid changes in consumers' preferences, the China milk scandal in 2008 and the 2014 Russian ban on EU food (e.g. Boulanger et al., 2016; Hirsch and Hartmann, 2014; Giles, 2015; Kapelko et al., 2016). In addition, as Keanne and Connor (2009) show, price volatility for dairy commodities has significantly increased in the last years caused by EU dairy prices that align more closely with world market prices. Finally, focusing on dairy processing firms is motivated by the high economic importance of this sector. With a $15.3 \%$ share of total turnover in 2012, the dairy processing industry is the largest economic sector within EU28 food manufacturing ${ }^{3}$ and plays a more important economic role than, e.g., in the US. Furthermore, more than half of the 20 worlds' largest dairy processors operate in the EU (Eurostat, 2017; Wijnands et al., 2007).

Our primary objectives are to derive measures of firms` tactical flexibility (henceforth flexibility) and to quantify the tradeoff with technical efficiency. Moreover, we assess how this tradeoff varies across firm size. We also test how firm-specific characteristics such as firm size, financial risk, capital intensity, age and legal form of business (e.g., cooperatives vs. investorindividually owned firms (IOFs)) are related to firm flexibility and efficiency. Finally, we assess whether flexibility can be an asset that helps firms to sustain profitability in times of economic crisis. For these analyses, the significant heterogeneity with respect to structural firm characteristics and market environments observed in the EU dairy processing industry provides an interesting case study (e.g., Hirsch and Hartmann, 2014). Amongst others, the four dairy processing industries included in this analysis differ profoundly with respect to product diversity, the share of cooperatives, and the impact that the 2008/09 financial crisis had on the economic performance of firms (Cassandro, 2003; Dries and Swinnen, 2004; Eurostat, 2017).

The article proceeds as follows. We first describe the derivation of the flexibility measure as well as the empirical implementation. The next section presents the data followed by the discussion of the results. Finally, some conclusions are drawn from this study.

\section{Economic Framework}

We follow Stigler (1939) and define firm flexibility as an attribute of production technology to handle output variations at lower costs. Empirically this is measured by the curvature -i.e., the second derivative- of a firm`s average variable cost (AVC) curve. Hence, given that

\footnotetext{
${ }^{3}$ According to Eurostat (2017) 12,331 firms operate in the EU28 dairy processing industry which generate a total turnover of $€ 140$ billion and provide employment for 370,000 people.
} 
$A V C=V C / y$, where $y$ is output and $V C$ is variable costs, a firm `s flexibility can be measured by (e.g. Renner et al. 2015):

Flex $=\partial^{2} A V C / \partial y^{2}=1 / y^{3}\left(V C_{y y} y^{2}-2 V C_{y} y+2 V C\right)$

The smaller the curvature of the AVC curve, the more flexible a firm`s production technology because variations in output will be associated with a smaller increase in AVC. In turn, greater curvature of the AVC curve implies that output adaption leads to a higher increase in AVC indicating lower firm flexibility (Renner, 2014). However, estimation of equation (1) needs cost functions that rely on firm-level input prices which are usually not publically available 4 .

An alternative approach to derive the firm flexibility measure is based on input-distance functions and the duality theorem (e.g., Diewert, 1971), and has been developed by Renner et al. (2014). Assuming that firms are cost minimizers the firm decision can be expressed by the following Lagrangian:

$L=\mathbf{p}^{\prime} \mathbf{x}-\lambda(D(\mathbf{x}, \mathbf{k}, y)-1)$

where $\mathbf{p}$ and $\mathbf{x}$ are vectors of prices and quantities for $n$ variable inputs while $\mathbf{k}$ represents the vector of quasi-fixed inputs. Finally, $D(\mathbf{x}, \mathbf{k}, y) \geq 1$ are input-distance functions. Firms with $D(\mathbf{x}, \mathbf{k}, y)=1$ produce on the efficient production frontier while the deviation from the frontier (i.e. $D(\mathbf{x}, \mathbf{k}, y)>1)$ represents the degree of inefficiency. Solving the minimization problem in equation (2) and applying the envelope theorem leads to expressions for $V C, V C_{y}$, and $V C_{y y}$ that only depend on first and second order derivatives of $D(\mathbf{x}, \mathbf{k}, y)$ with respect to $\mathbf{x}$ and $y^{5}$ :

$$
\begin{aligned}
& V C=1 / \sum_{n} D_{X n} \\
& V C_{y}=-V C * D_{y} \\
& V C_{y y}=V C\left(D_{y}^{2}+\mathbf{D}_{\mathbf{y x}}\left(\mathbf{D}_{\mathbf{x x}}+\mathbf{D}_{x} \mathbf{D}_{x}^{\prime}\right)^{-1} \mathbf{D}_{\mathbf{x y}}+D_{y y}\right)
\end{aligned}
$$

\footnotetext{
${ }^{4}$ An alternative could be to use average regional raw milk prices which are publicly available (e.g. AMI, 2017). However, this involves several disadvantages: i) Regional prices are usually derived excluding reporting units with less than 20 employees (Eurostat, 2012) hence neglecting information for the large number of small and micro sized firms operating in EU dairy processing. ii) Using regional input prices as a proxy for firm specific prices can lead to insufficient variance for a consistent estimation of cost functions (Renner, 2014). Finally, deriving firm specific prices by dividing input costs per firm by respective quantities employed is not feasible in the present case as the latter are not available from the balance sheet data.

${ }^{5}$ See Renner (2014) and Renner et al. (2015) for the derivation of the variable cost function and its first and second order derivatives with respect to $y$.
} 
Inserting equations (3)-(5) into equation (1) and rearranging the terms leads to a primal flexibility measure for each firm that can be estimated based on monetary values of inputs and output which are usually observable:

Flex $=1 / y^{3}\left[\left(1 / \sum_{n} D_{X n}\left(D_{y}^{2}+\mathbf{D}_{\mathbf{y x}}\left(\mathbf{D}_{\mathbf{x x}}+\mathbf{D}_{\mathbf{x}} \mathbf{D}_{\mathbf{x}}^{\prime}\right)^{-1} \mathbf{D}_{\mathbf{x y}}+D_{y y}\right)\right) y^{2}+\right.$

$\left.2\left(D_{y} y+1\right) / \sum_{n} D_{X n}\right]$

where $D$.. and D.. are (matrices of) first and second order derivatives of the input-distance function $D(\mathbf{x}, \mathbf{k}, y)$ with respect to inputs $\mathbf{x}$ and output $y$. Note that since flexibility is measured by the curvature of the AVC curve higher values of Flex imply less flexible production systems and vice versa.

\section{Empirical Implementation}

\subsection{Estimation of input-distance functions}

To avoid restrictions on production and substitution elasticities, we use the following translogform for the input-distance function $D(\mathbf{x}, \mathbf{k}, y)$ that based on the assumption of different technologies can be estimated separately for each of the four included dairy processing sectors using stochastic frontier analysis:

$$
\begin{aligned}
& \ln D(\mathbf{x}, \mathbf{k}, y)=\beta_{0}+\beta_{1} \ln (y)+\sum_{n=1}^{N} \beta_{n} \ln \left(x_{n}\right)+\sum_{m=1}^{M} \beta_{m} \ln \left(k_{m}\right)+0.5 \beta_{2}\left(\ln (y)^{2}\right)+0.5 \sum_{n}^{N} \sum_{l}^{L} \beta_{n l} \ln \left(x_{n}\right) \ln \left(x_{l}\right) \\
& +0.5 \sum_{m=1}^{M} \sum_{k=1}^{K} \beta_{m k} \ln \left(k_{m}\right) \ln \left(k_{k}\right)+\sum_{n=1}^{N} \beta_{n y} \ln \left(x_{n}\right) \ln (y)+\sum_{m=1}^{M} \beta_{m y} \ln \left(k_{m}\right) \ln (y)+\sum_{n=1}^{N} \sum_{m=1}^{M} \beta_{n m} \ln \left(x_{n}\right) \ln \left(k_{m}\right)+\sum_{t=1}^{T} \phi_{t} t
\end{aligned}
$$

where $\phi_{t}$ is a set of year effects (Kumbhakar et al. 2015). The estimated values of equation (7) can then be used to calculate the flexibility measure defined by equation (6) for each firm. $D(\mathbf{x}, \mathbf{k}, y)$ shall be non-decreasing and concave in variable inputs $(\mathbf{x})$, and non-increasing in output (y) and quasi-fixed inputs (k) (Coelli and Perelman 2000; Kumbhakar et al. 2015) ${ }^{6}$. A necessary and sufficient condition for the concavity of $D(\mathbf{x}, \mathbf{k}, y)$ with respect to $\mathbf{x}$ is negative

\footnotetext{
${ }^{6}$ The property of concavity in $\mathbf{x}$ is derived from the convexity of the underlying input requirement set (e.g. Nemoto and Furumatsu, 2014). O'Donnell and Coelli (2005) and Färe et al. (1993) show that duality results such as shadow prices, rely on these theoretical properties and that violations can lead to implausible conclusions on efficiency levels and flexibility.
} 
semi definiteness of the Hessian matrix of second derivatives of $D$ w.r.t. variable inputs (Diewert and Wales 1987). Morey (1986) shows that this is the case if all Eigenvalues of the Hessian matrix are smaller or equal than zero (Renner et al. 2014) ${ }^{7}$. Moreover, we assume homogeneity in variable inputs which is imposed by normalizing $D(\mathbf{x}, \mathbf{k}, y)$ with one of the variable inputs (Färe and Primont 1995, Coelli and Perelman 2000, Renner 2014). ${ }^{8}$ For the stochastic frontier analysis, we assume that for firm $i$ and time $t$ :

$\ln D_{i t}(\mathbf{x}, \mathbf{k}, y)=u_{i t}-v_{i t}$

where $v_{i t}$ is a random error with $v_{i t} \sim N\left(0, \sigma_{v}\right)$ and $u_{i t}$ represents technical inefficiency (Belotti et al. 2013, Renner et al. 2014), for which we assume a truncated normal distribution (Battese and Coelli 1995).

Normalizing equation (7) by variable input, $x_{1}$, inserting equation (8) and rearranging the terms yields the following empirically estimable model (Renner, 2014; Kumbhakar et al., 2015) ${ }^{9}$ :

$$
\begin{aligned}
& -\ln \left(x_{1 i t}\right)=\beta_{0}+\beta_{1} \ln \left(y_{i t}\right)+\sum_{n=2}^{N} \beta_{n} \ln \left(\widetilde{x}_{n i t}\right)+\beta_{m} \ln \left(k_{i t}\right)+0.5 \beta_{2}\left(\ln \left(y_{i t}\right)^{2}\right)+0.5 \sum_{n=2}^{N} \sum_{l=2}^{L} \beta_{n l} \ln \left(\widetilde{x}_{n i t}\right) \ln \left(\widetilde{x}_{l i t}\right) \\
& +0.5 \beta_{m}\left(\ln \left(k_{i t}\right)^{2}\right)+\sum_{n=2}^{N} \beta_{n y} \ln \left(\widetilde{x}_{n i t}\right) \ln \left(y_{i t}\right)+\beta_{m y} \ln \left(k_{i t}\right) \ln \left(y_{i t}\right)+\sum_{n=1}^{N} \beta_{n m} \ln \left(\widetilde{x}_{n i t}\right) \ln \left(k_{i t}\right)+\phi_{t}-u_{i t}+v_{i t}
\end{aligned}
$$

where $\tilde{x}_{n i t}=x_{n i t} / x_{1 i t}$ and $\ln \left(\widetilde{x}_{n i t}\right)=\ln \left(x_{n i t}\right)-\ln \left(x_{1 i t}\right)$.

We assume separate technologies for the four included dairy processing industries. Equation (9) is then estimated separately for each of the four countries using the stochastic frontier paneldata approach proposed by Battese and Coelli (1995) that allows for heterogeneity of inefficiency over time (Belotti et al., 2013). For each country, the resulting vector of estimated

\footnotetext{
${ }^{7}$ Morey (1986) also shows that a necessary condition for concavity is that the diagonal elements of the Hessian are negative.

${ }^{8}$ Homogeneity in variable inputs implies that $\sum_{n} \beta_{n}=1$ and $\sum_{l} \beta_{n l}=\sum_{y} \beta_{n y}=\sum_{m} \beta_{n m}=0$ for all n. Moreover, the following restriction for symmetry needs to hold: $\beta_{n l}=\beta_{l n}$ for all $l$ and $n$ (Kumbhakar et al., 2015).

${ }^{9}$ According to Renner (2014) the choice of the input variable used to normalize (7) does not alter the results and does not lead to problems of endogeneity when using a translog-form for the input-distance function (e.g. Coelli and Perelman, 2000; Kumbhakar et al., 2013).
} 
coefficients ( $\hat{\boldsymbol{\beta}}$ ) can be directly inserted into the distance function defined by (7). This, in turn, enables to calculate the first and second order derivatives of the input-distance function $D(\mathbf{x}, \mathbf{k}, y)$ needed to derive the flexibility measure defined by (6) for each firm $i$ in year $t$. Moreover, the estimation of input distance functions produces for each firm $i$ and year $t$ a measure of technical efficiency defined by $T E=\exp \left(-\hat{u}_{i t}\right)$ that can be used to quantify the tradeoff between flexibility and technical efficiency (Belotti et al., 2013).

\subsection{Drivers of flexibility and efficiency}

In a second step, we test which firm-specific factors are related to flexibility and efficiency. Based on Mills and Schumann`s (1985) "theory of industry structure with fluctuating demand" firm size is our main variable of interest. However, in line with previous literature, we also include the following firm-specific variables that are potentially related to flexibility and efficiency: age, financial risk, capital intensity, and legal form (e.g., Weiss, 2001; Renner, 2014).

Regarding firm size, which we measure by total assets, ambiguous findings have been reported in the literature. Smaller firms have often been found to be more flexible in adjusting their production to changing demand environments (e.g., Fiegenbaum and Karnani, 1991; Renner et al., 2014). Thus, in accordance with Mills and Schumann (1985), in a dynamic market and policy environment, small firms might have an advantage over large firms in the form of flexibility while larger firms tend to be more efficient (e.g., Das et al., 1993).

With respect to age, measured by the years a firm is in operation ${ }^{10}$, it can be expected that older firms benefit from experience in reacting to external shocks. However, Majumdar (1997) argues that aging leads to inertia and bureaucratic ossification of firms and reduced ability to react to changing economic circumstances. Along these lines, Loderer and Waelchli (2010) found that firms' age leads to organizational rigidities and lower ability to adapt to economic fluctuations. Regarding the relationship of age and efficiency Jovanovic (1982) proposed a model where efficient firms survive over time due to greater acquired industrial experience leading to a positive age-efficiency correlation. However, related empirical literature either points to an insignificant or negative relationship between age and efficiency that can be caused by the fact that younger firms employ more advanced technology and capital (Hill and Kalirajan, 1993; Lundvall and Battese, 2000).

\footnotetext{
${ }^{10}$ Note that previous literature has often used the age of the firm's manager or farm operator (e.g. Weiss, 2001; Renner et al. 2014).
} 
Furthermore, we account for firms' financial risk using the gearing ratio which is defined as the ratio of non-current liabilities plus loans to shareholder funds. The gearing ratio is driven by various market and institutional characteristics such as access to credit (e.g., Renner, 2014). Moreover, gearing ratio is also determined by the risk exposure of the firm. The risk balancing hypothesis indicates that the gearing ratio decreases with risk exposure, given that decision makers are risk averse (e.g., Collins, 1985; Mishra and Lence, 2005). Since risk exposure is negatively related to flexibility, gearing ratio and production flexibility might be positively correlated. However, it should be noted that the financial pressure associated with debt can also reduce free cash flow and flexibility but in turn lead to a better utilization of firm resources implying higher efficiency (Chaddad and Mondelli, 2013).

Capital intensity (i.e., investments in fixed production factors) is measured by the ratio of tangible fixed assets in total assets. Renner et al. (2014) show that farming production systems with a high capital intensity (high share of fixed production factors) are less flexible (e.g., Das et al., 1993). However, for dairy processing companies, it can also be the case that higher capital intensity reflects investments in new technologies with a broader manufacturing focus (e.g., for cheese processing) which are associated with an easier adaptability of production capacities leading to higher flexibility. Moreover, capital intensity is expected to negatively influence efficiency due to a less efficient utilization of fixed and working capital and higher barriers to exit unprofitable operations (Buzzell and Gale 1987; Berman et al., 1999).

An important feature of the EU dairy processing sector is a significant share of cooperatives (Hirsch and Hartmann, 2014). Recent developments such as the abolishment of the quota system have initiated an intense debate on the competitive advantages of cooperatives as opposed to investor-individually owned firms (IOFs). Soboh et al. (2012) show that cooperatives are constrained to let each member provide its profit-maximizing quantity which in turn can lead to lower flexibility in determining the optimal size (Soboh et al., 2011). Hendrikse and Veerman (2001) argue that democratic decision making in cooperatives reduces flexibility in the reaction to market changes. In addition, unclear shared ownership rights can result in complicated decision-making processes hampering flexible management of dairy cooperatives (Wilkin et al., 2006). We, therefore, hypothesize that production flexibility of cooperatives is lower compared to IOFs. With respect to efficiency, empirical literature points towards lower technical efficiency of cooperatives compared to IOFs due to higher costs of control, lower efficiency in input use as well as free rider problems (e.g., Nilsson, 2001; Cook, 1995; Soboh et al., 2012) 
To adequately capture the high standard deviation and skewness of the estimated Flex measures (described below) and potential endogeneity problems we estimate the drivers of flexibility and efficiency as follows. We first assess for each country the necessity to apply a two-stage least squares (2SLS) instrumental variable approach by testing which of the above discussed explanatory variables are to be treated as endogenous when estimating their impact on flexibility and efficiency. This is important as 2SLS is less efficient than fixed effects estimation when explanatory variables are exogenous but incorrectly treated as endogenous (Wooldridge, 2006). Subsequently, we either apply 2SLS fixed effects (in cases where one or more of the independent variables is to be treated as endogenous) or standard fixed effects regression (in cases where all variables are exogenous) to the flexibility and efficiency models in each country. As the 2SLS and fixed effect estimators are not robust to extreme values similar to Renner (2014), we adjust the Flex measure by deleting the top and bottom 1\% observations. We use lagged values of endogenous variables as instruments and assess the validity and strength of these instruments using relevant first-stage statistics. As a robustness check, we then use a (robust) 0.5-quantile regression panel estimator applied to all values of the Flex measure (including extreme values) (Baker et al., 2016; Powell, 2016). In contrast to (2SLS) fixed-effects estimation, this estimator additionally allows to include the time-invariant variable capturing firms` legal form (IOF vs. cooperative). Similar to the above approaches the robust estimator takes into account endogeneity of independent variables via instrumental variable (IV) regression (Baker et al., 2016; Powell, 2016).

\subsection{Flexibility and profitability during the economic crisis}

Previous literature has addressed the impact of flexibility on profitability (e.g., Fiegenbaum and Karnani, 1991). For example, Aigner and Weiss (1998) show that firms flexibility in adjusting their labor force positively influences profitability. Also, Merschmann and Thonemann (2011) detect a positive relationship between profitability and firms' supply chain flexibility particularly in uncertain environments. We are interested in whether flexibility helps in sustaining firm profitability in times of economic crisis. For this purpose, we make use of the 2008-09 financial crisis, a period which was also characterized by significant spikes in milk prices, as a natural experiment (e.g., Hemme et al., 2013).

Starting with Mueller (1990) an autoregressive process of order one AR(1) has become the standard approach to model firm profitability as a dynamic process (e.g., Hirsch, 2018):

$$
R O A_{i, t}=c+\lambda R O A_{i, t-1}+\alpha_{1} d_{c}+\alpha_{2} \text { Flex }_{i, t}+\alpha_{3} d_{c} \text { Flex }_{i, t}+\sum_{j=4}^{n} \alpha_{j} V_{j, i, t}+\phi_{t}+\varepsilon_{i, t}
$$


where $R O A_{i, t}$ reflects return on assets of firm $i$ in period $t$ measured as earnings before interest and taxation divided by total assets. The AR(1)-coefficient $\hat{\lambda}$ reflects the persistence and hence dynamic behavior of profitability over time (e.g., Goddard et al., 2005). The general impact of flexibility on profitability is measured by $\hat{\alpha}_{2} . d_{c}$ is a dummy with value one for the crisis period and zero otherwise. The impact of the economic crisis on profitability is thus captured by $\hat{\alpha}_{1}$ while $\hat{\alpha}_{3}$ reflects the impact of flexibility during times of economic crisis. Besides flexibility we additionally consider the impact of firm specific factors $\left(V_{j, i, t}\right)$ such as size, financial risk, capital intensity, age and legal form that potentially affect firm`s profitability. Finally, $\phi_{t}$ represents year effects for periods outside the crisis and $\varepsilon_{i, t}$ an error term which is composed of an unobserved time-invariant fixed effect $\left(\tau_{i}\right)$ and an observation-specific error $\left(e_{i, t}\right)$.

The dynamic panel model specified by equation (10) is affected by an upward bias of the autoregressive (AR) coefficient $(\hat{\lambda})$ if estimated with OLS as $\operatorname{Cov}\left(R O A_{i, t-1} ; \tau_{i}\right) \neq 0$. The adequate econometric specification to avoid this endogeneity bias is Arellano and Bond's (1991) GMM estimator which generates consistent and unbiased estimates due to the removal of time-invariant firm effects through first-order differentiation. The first-differenced equation is then estimated using lags of $R O A_{i, t-1}$ and all other potentially endogenous firm-specific variables in $V_{j, i, t}$ as valid instruments (Baltagi, 2008).

\section{Data}

The estimation is based on accounting data of dairy processors provided by AMADEUS, a trans-European database of financial information provided by Bureau van Dijk (e.g., Hirsch and Gschwandtner, 2013). AMADEUS comprises firms of all legal forms and size classes which is important for an analysis of the EU dairy processing sector which is mainly $(99 \%)$ characterized by small- and medium-sized enterprises (SMEs) (e.g., Wijnands et al. 2007). We focus on four countries, reflecting important dairy processors with a large gradient concerning geographical location, production technologies and market structures (Wijnands et al. 2007): France, Italy, Poland, and Spain. Together these countries account for 55\% of the companies and $44 \%$ of total EU-28 dairy processing turnover (Eurostat 2017). ${ }^{11}$ We use all firms with complete data for the period 2006-2014 leading to an initial sample of 2,186 dairy processors.

\footnotetext{
${ }^{11}$ Germany the EU28 leader regarding food industry turnover is not covered by our study due to a lack of data caused by the fact that the majority of non-publicly quoted firms was not legally obligated to publish financial data until the year 2007 (Hirsch, 2014).
} 
Table 1 indicates that this sample represents $32 \%$ of the firms operating in the dairy sectors of the included countries. Moreover, the samples adequately represent the variation of the number of companies across countries present in the population. As firm size is a crucial factor for the economic performance of firms in the food sector (Wijnands et al. 2007, Hirsch and Gschwandtner, 2013) Table 1 further presents a comparison of the sample with the population by size classes. It can be observed that micro-sized firms are, despite the nonexistence of a minimum size criterion for the inclusion of firms in the AMADEUS database, somewhat underrepresented in most countries. Moreover, the four countries included in the present study provide an interesting setting to test for differences in flexibility across legal forms because the importance of cooperatives varies significantly across countries. More specifically, the share of cooperatives is at around $20 \%$ in most countries of the EU, including France, Italy, and Spain. In contrast, Poland -the only eastern European country in our sampleconstitutes a particular case where more than $70 \%$ of firms are cooperatives (Hirsch and Hartmann, 2014; Dries et al. 2009; Dries and Swinnen, 2004; Wilkin et al., 2006). Cooperatives are adequately represented in our samples allowing for a detailed comparison of flexibility between those firms and IOFs ${ }^{12}$.

Although AMADEUS data has the advantage that financial statements are extensively harmonized across countries the problem remains that accounting data can be subject to biases and anomalies caused by, e.g., profit-smoothing and cross-subsidization procedures and therefore do not necessarily reflect real economic performance (e.g., Fisher and McGowan, 1983; Long and Ravenscraft, 1984). To identify resulting multivariate outliers in the sample, we apply the 'bacon' algorithm proposed by Billor et al. (2000), which identifies a set of outliers based on Mahalanobis distances (Weber, 2010). The application of the bacon algorithm leads to the exclusion of 285 (95 France; 81 Italy; 16 Poland; 93 Spain) firm/year observations (i.e., $1.4 \%$ of the observations) across the four countries. Moreover, we removed unreasonable observations such as negative costs or revenues as well as observations for which total assets are unequal to total liabilities and equity. The final dataset comprises 19,291 firm/year observations.

\footnotetext{
${ }^{12}$ While the share of cooperatives in the samples for France, Italy and Spain is $26 \%$ it exceeds $55 \%$ in the Polish sample.
} 
Table 1: Comparison of the sample with the population (for the year 2014)

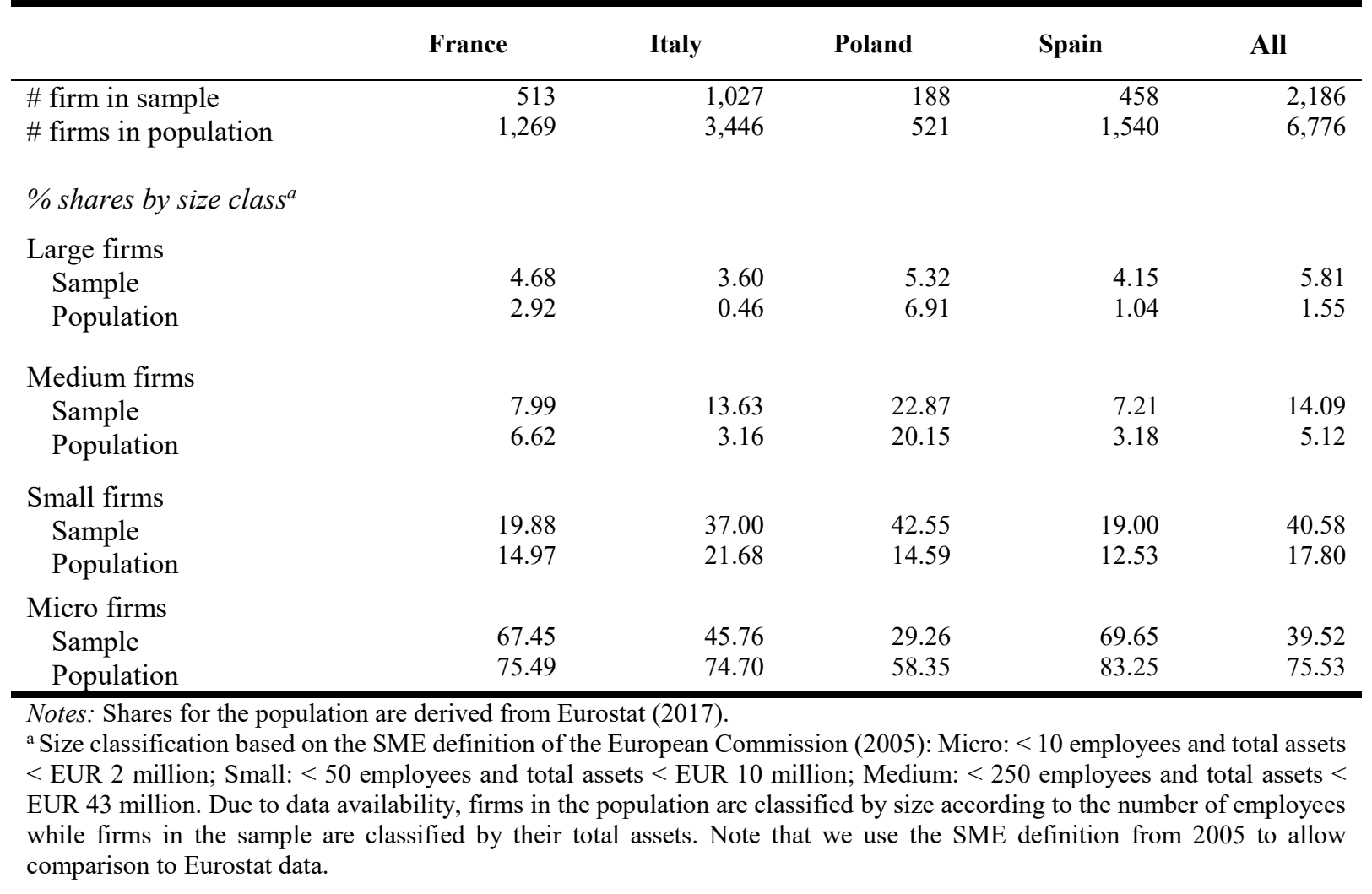

For each firm operating revenue ${ }^{13}$ is used as the output measure $(y)$. Although it is highly likely that the dairy processors in our sample produce more than one product ${ }^{14}$, total revenue from all products is the only relevant output measure available in the AMADEUS database (e.g., Soboh et al., 2012). ${ }^{15}$ Material- and staff costs are used as variable inputs $\left(x_{1}\right.$ and $\left.x_{2}\right)$ that can be adapted within one year (the time unit of the analyzed sample). Material costs reflect all costs of purchasing input materials ahead of the processing operation. In the case of the dairy processing industry, this input mainly consists of the costs of purchasing raw milk (Wijnands et al., 2007). In turn, fixed assets defined as the value of land, buildings, machinery, patents, and brands are used as a single quasi-fixed input ( $k$ ) (BvD, 2007; Soboh et al., 2012). All inputs are measured in Euros and deflated using industrial producer price indexes for the dairy manufacturing industry in each country (with the base year 2010) provided by Eurostat (2017a). Output, in turn, is deflated using the country-level harmonized index of consumer prices for milk, cheese, and eggs (Eurostat, 2017b; Eurostat, 2012).

\footnotetext{
${ }^{13}$ We use revenues to account for both quantity and quality of production.

${ }^{14}$ Raw milk is the base for a heterogeneous set of products meeting the demand of both consumers (e.g. drinking milk, yoghurt, butter or cheese) and other food industry subsectors (e.g. skimmed milk powder or whey) (Wijnands, et al. 2007).

15 The flexibility measure defined by (6) is therefore particularly derived for the one-output case. For the multioutput case we refer to Renner et al. (2014) who develop a multi-output flexibility measure that can further be segmented into scope, convexity and scale effects.
} 
Table 2 reports descriptive statistics on the output and input measures as well as for the remaining firm-specific variables. It can be observed that material costs (costs of raw milk) represent the major cost factor in all countries. The highest mean revenue can be found for Polish firms, while Spanish firms operate on average significantly below the grand mean of revenue of countries included in the sample. Moreover, the Polish sample constitutes the oldest firms with an average of around 35 years since incorporation while the mean age in the remaining countries is between 16-30 years. The Italian sample significantly exceeds all other countries concerning financial risk as indicated by the highest gearing ratio (an average of 194\%), while the gearing ratio is, on average, lowest in Poland (52\%). Finally, compared to the remaining countries, the mean capital intensity is highest in Poland and Spain (0.467 and 0.429) and considerably lower in France and Italy (0.272).

Table 2. Descriptive statistics of out- / input measures and firm characteristics (2006-2014)

\begin{tabular}{|c|c|c|c|c|c|}
\hline & France & Italy & Poland & Spain & All \\
\hline \multirow[t]{2}{*}{ \# obs. } & 4,497 & 9,170 & 1,665 & 3,959 & 19,291 \\
\hline & \multicolumn{5}{|c|}{ Means (Standard deviations) } \\
\hline Operating Revenue $(1000 €)$ & $\begin{array}{c}14,273.380 \\
(114,990.00)\end{array}$ & $\begin{array}{c}8,376.822 \\
(24,236.45)\end{array}$ & $\begin{array}{l}22,362.420 \\
(34,695.03)\end{array}$ & $\begin{array}{c}4,904.624 \\
(13,850.81)\end{array}$ & $\begin{array}{l}10,233.760 \\
(58,994.26)\end{array}$ \\
\hline Material costs $(1000 €)$ & $\begin{array}{c}6,448.598 \\
(23,598.51)\end{array}$ & $\begin{array}{c}6,339.221 \\
(18,612.87)\end{array}$ & $\begin{array}{l}18,193.290 \\
(28,261.50)\end{array}$ & $\begin{array}{c}4,260.885 \\
(12,105.46)\end{array}$ & $\begin{array}{c}6,777.376 \\
(20,046.96)\end{array}$ \\
\hline Staff costs $\quad(1000 €)$ & $\begin{array}{c}1,455.00 \\
(15,628.37)\end{array}$ & $\begin{array}{c}779.953 \\
(1,873.70)\end{array}$ & $\begin{array}{l}1,296.260 \\
(1,695.64)\end{array}$ & $\begin{array}{l}432.019 \\
(948.41)\end{array}$ & $\begin{array}{c}902.961 \\
(7,911.72)\end{array}$ \\
\hline Fixed Assets $(1000 €)$ & $\begin{array}{c}4,157.878 \\
(58,039.87)\end{array}$ & $\begin{array}{l}2,350.098 \\
(6,953.14)\end{array}$ & $\begin{array}{c}4,820.085 \\
(7,685.246)\end{array}$ & $\begin{array}{l}1,422.707 \\
(3,624.71)\end{array}$ & $\begin{array}{c}2,772.008 \\
(28,176.14)\end{array}$ \\
\hline Total Assets $(1000 €)$ & $\begin{array}{c}9,010.570 \\
(102,430.00)\end{array}$ & $\begin{array}{c}7,243.543 \\
(18,310.44)\end{array}$ & $\begin{array}{l}9,525.160 \\
(15,196.46)\end{array}$ & $\begin{array}{l}3,113.502 \\
(7,180.91)\end{array}$ & $\begin{array}{c}7,005.835 \\
(50,982.08)\end{array}$ \\
\hline $\begin{array}{l}\text { Age (in years since } \\
\text { incorporation) }\end{array}$ & $\begin{array}{l}26.484 \\
(22.73)\end{array}$ & $\begin{array}{l}29.903 \\
(22.82)\end{array}$ & $\begin{array}{l}35.169 \\
(28.38)\end{array}$ & $\begin{array}{l}16.087 \\
(9.34)\end{array}$ & $\begin{array}{l}26.719 \\
(22.12)\end{array}$ \\
\hline Gearing (in \%) & $\begin{array}{c}82.610 \\
(126.65)\end{array}$ & $\begin{array}{l}193.631 \\
(216.09)\end{array}$ & $\begin{array}{l}52.143 \\
(83.94)\end{array}$ & $\begin{array}{l}108.273 \\
(165.53)\end{array}$ & $\begin{array}{l}136.162 \\
(186.17)\end{array}$ \\
\hline $\begin{array}{l}\text { Capital Intensity } \\
\text { (\% of tangible fixed assets in } \\
\text { total assets) }\end{array}$ & $\begin{array}{l}0.272 \\
(0.19)\end{array}$ & $\begin{array}{l}0.272 \\
(0.23)\end{array}$ & $\begin{array}{l}0.467 \\
(0.19)\end{array}$ & $\begin{array}{l}0.429 \\
(0.23)\end{array}$ & $\begin{array}{l}0.321 \\
(0.23)\end{array}$ \\
\hline
\end{tabular}

Notes: Standard deviations in parentheses

\section{Results and discussion}

\subsection{Flexibility, technical efficiency, and tradeoffs}

The results for the stochastic frontier panel models defined by equation (9) for each country are reported in Table A1 in the appendix. The lower panel of Table A1 indicates that for all cases 
$D(\mathbf{x}, k, y)$ turns out as non-increasing in output and in the vast majority of cases as nondecreasing in variable inputs. In contrast to our expectations fixed assets $(k)$ are found to increase $D(\mathbf{x}, k, y)$ in the majority of cases. However, the identified elasticities of $k$ at the sample mean are close to zero indicating that $k$ on average neither increases nor decreases variable costs. This indicates that only limited gains in terms of reduced variable costs from investment in (quasi) fixed assets can be exploited in the EU dairy processing sector. For further analysis, we have dropped all results which are decreasing in variable inputs and non-concave ${ }^{16}$.

Table 3 provides insights into the degree of flexibility of EU dairy processing firms ${ }^{17}$. Due to the non-normal and highly variable distribution of the estimated Flex values (see Figure A1), we report medians and median absolute deviations as the robust measures to summarize the results ${ }^{18}$. For the interpretation of the results, it is important to keep in mind that higher values of the Flex measure indicate greater curvature of the AVC curve, implying less flexible production. On the other hand, lower Flex values are associated with higher flexibility. The results in the upper row of Table 3 hence indicate that flexibility is highest in Poland and Italy while significantly less flexible production prevails in France and Spain ${ }^{19}$. Unlike the multioutput Flex measure (e.g., Renner et al. 2014; Bokusheva and Čechura 2017) the single output measure used in this study cannot be decomposed into scope, convexity and scale effects. We can therefore not distinguish how far the differences across countries are driven by these sources of flexibility. However, following Mills and Schumann`s (1985) theory we determine how far flexibility is related to efficiency and assess differences across firm size.

\footnotetext{
${ }^{16}$ Non-concave results were identified based on the level of individual observations via the Eigenvalues and diagonal elements of the Hessian matrix of second derivatives of $D$ w.r.t. x. This lead to the exclusion of 1,574, 857, 680, and 656 year/firm observations in France, Italy, Poland and Spain respectively. We have also estimated equation (9) using different stochastic frontier panel-data approaches such as the true fixed- or random-effects estimators (Greene 2005a, 2005b) which assume an exponential distribution for $u_{i t}$. However, these estimations lead to a higher number of excluded observations w.r.t. the above criteria. We therefore opted for the approach by Battese and Coelli (1995) with a truncated normal distribution for $u_{i t}$ as the superior estimation strategy.

${ }^{17}$ Note that the input distance approach implies that variable inputs are valued with shadow prices and not with real market prices. If shadow prices are below market prices it can be that flexibility is upward biased and vice versa. Given that real market prices are not observable a comparison to shadow prices, which can be derived from partial derivatives of the input distance function w.r.t. inputs (e.g. O’Donnell and Coelli 2005) is not possible.

${ }^{18}$ All classical tests for normality reject the null of normally distributed Flex measures in all countries. Note that previous literature (e.g. Renner et al. 2014) deletes extreme flexibility values and afterwards report mean values. As a robustness check and to enable better comparability to previous literature we also follow this approach in Table A2 in the appendix. The central statement of the results is unaffected by this procedure and the values are in the range of flexibility values reported in previous literature (e.g. Renner et al. 2014; Bokusheva and Čechura 2017)

${ }^{19}$ Based on a two-sample Wilcoxon rank-sum test for the equality of medians, flexibility differs significantly between all four countries. Note that although flexibility in each country is measured based on separate distance functions and hence different technologies a comparison between countries is possible as Flex represents the second derivative of AVC which has a uniform interpretation across functions. Hence, other than efficiency Flex is not derived with reference to the distance function but relates to its functional form.
} 
Table 3. Median flexibility and correlations with technical efficiency (2006-2014)

\begin{tabular}{lcccc}
\hline & France & Italy & Poland & Spain \\
\hline Flex & 0.0041 & 0.0006 & 0.0002 & 0.0117 \\
& $(0.0041)$ & $(0.0006)$ & $(0.0002)$ & $(0.0116)$ \\
Technical Efficiency & 0.9449 & 0.9198 & 0.9991 & 0.9192 \\
& $(0.0083)$ & $(0.0078)$ & $(0.0000)$ & $(0.0172)$ \\
\# obs. & 2,413 & 6,462 & 407 & 2,382
\end{tabular}

Spearman rank correlations between flexibility and efficiency

$\begin{array}{lcccc}\text { All firms } & -0.024 & -0.133^{* * *} & -0.109 * * & -0.094 * * * \\ \text { Small } & -0.024 & -0.124 * * * & 0.009 & -0.086^{* * *} \\ \text { Medium } & 0.211^{* * *} & -0.083^{* * *} & 0.186 & -0.172^{* *} \\ \text { Large } & 0.231^{* *} & 0.045 & 0.652^{* *} & 0.031\end{array}$

Pearson correlations between adjusted flexibility ${ }^{a}$ and efficiency

\begin{tabular}{|c|c|c|c|c|}
\hline All firms & -0.010 & $-0.172 * * *$ & $0.285^{* * *}$ & $-0.147 * * *$ \\
\hline Small & -0.006 & $-0.176^{* * *}$ & $0.309^{* * *}$ & $-0.153 * * *$ \\
\hline Medium & 0.104 & $0.153 * * *$ & $0.228^{*}$ & $-0.613 * * *$ \\
\hline Large & 0.037 & $0.116^{* *}$ & $0.513 *$ & 0.125 \\
\hline
\end{tabular}

Row two of Table 3 reveals that median technical efficiency, for all countries is close to the maximum value of 1 indicating that EU dairy processors operate highly efficient ${ }^{20}$. In the following, we assess possible tradeoffs between technical efficiency and flexibility. Given the non-normal distribution of Flex we use Spearman's rank correlation as a robust measure to capture the tradeoff with efficiency (Shevlyakov and Smirnov, 2011). As a robustness check, we apply sample correlation coefficients to Flex and efficiency where the former is adjusted by deleting the top and bottom 1\% observations. Table 3 reveals the presence of a positive correlation between the Flex measure and technical efficiency for large firms and in the majority of cases also for medium-sized firms. These results indicate a significant negative relationship between flexibility and technical efficiency and hence a tradeoff between the two characteristics for these firms ${ }^{21}$. Our findings for large and medium firms are therefore mainly consistent with Mills and Schumann`s (1985) theory. Hence particularly for large and medium-sized firms, this indicates that a sole focus on firm efficiency would be misleading. In contrast, firms' ability to adjust to shocks needs to be explicitly considered.

\footnotetext{
${ }^{20}$ Previous literature has provided mixed evidence on the technical efficiency of food processing firms. For example, Dimara et al. (2008) found mean efficiency values for the Greek food industry between 0.191 and 0.210. In contrast, Ali (2007) reports average values of $>0.90$ for the Indian meat processing industry. Soboh et al. (2012) found differences in efficiency between cooperatives $(0.428)$ and IOFs $(0.642)$ in the EU dairy processing industry. ${ }^{21}$ See Figure A2 in the appendix for a graphical illustration of the tradeoff by size class.
} 
Except for Poland, a tradeoff cannot be detected for small-sized firms. On the contrary, particularly in Italy and Spain flexibility and efficiency tend to be positively related for small firms. Note that the model by Mills and Schumann (1985) is built on the assumption of perfectly competitive markets implying that the presence of market power or industry concentration potentially offsets the flexibility/efficiency tradeoff (Zimmermann, 1995; Weiss, 2001). Accordingly, Röller and Tombak (1993) and Eaton and Schmitt (1994) detect that in strongly concentrated industries the number of firms adopting flexible production systems is disproportionately high. In addition, Aigner and Weiss (1998) show that the impact of labor flexibility on profits becomes less important when industry concentration is high. This might imply that in non-competitive market environments the tradeoff between flexibility and efficiency is mitigated. We therefore calculated five-firm concentration ratios and find that dairy processing sectors in the four included countries are only moderately concentrated during the analyzed time span ranging from $26.9 \%$ in Spain to $49 \%$ in Italy ${ }^{22}$. Nevertheless, while there is evidence of fierce competition amongst dairy processors due to high retailer bargaining power (e.g., Hirsch and Hartmann 2014), the previous literature indicates that smaller firms can exploit market power in niche markets enabling them to circumvent bargaining power of large retailers. This might offset the tradeoff between flexibility and efficiency for smaller firms. For example, Shaw et al. (1999) show for the UK and Portuguese food sector that small firms despite strong competition due to internationalization and an increasing dominance of retailers can survive by exploiting niche segments and supplying quality driven regional markets. Similarly, Ilbery and Kneafsey (1999) point to the potential of small producers in the EU food industry that operate in unique geographical origins to successfully resist the encroachment of large multinational firms. In fact, there exists for example a huge variety of geographical indications in the European dairy sector (e.g, Moschini et al., 2008). Moreover, it is commonly observed that small niche producers organize themselves in networks within the same geographical area leading to improved market access and competitiveness (Olsen et al. 2012).

Another reason why a tradeoff is not detected for the entire sample of dairy processing firms might be that our data is characterized by a unique coverage of small- and micro-sized firms which are not included in other studies. For example, previous literature detecting tradeoffs between flexibility and efficiency for U.S. manufacturing firms is mainly based on the Compustat database which only includes publicly quoted and hence larger firms implying

\footnotetext{
${ }^{22}$ These values are similar to those presented in previous literature (e.g. Soregaroli et al., 2011; Serra and Goodwin, 2003).
} 
that the tradeoff for small and micro-sized firms is not considered in these studies (e.g., Mills and Schumann, 1985; Fiegenbaum and Karnani, 1991; Das et al., 1993).

\subsection{Drivers of flexibility and efficiency}

Tables 4 and 5 show the estimation results for the drivers of flexibility and efficiency. Two separate models, one for drivers of flexibility one for drivers of technical efficiency, are estimated for each country. As described above we focus on the relationship of firm size with flexibility and efficiency in accordance with Mills and Schumann`s (1985) model but also consider the relevance of age, the gearing ratio, capital intensity, and legal form. We first test which of the independent variables are to be treated as endogenous using the DavidsonMacKinnon test (Table A3). For the Flex models this test rejects in none of the cases the null hypothesis of exogeneity implying that for all countries fixed effects estimation is applied. Regarding efficiency, gearing turned out as endogenous in the case of France and Italy while the null hypothesis of exogeneity is rejected for capital intensity in the case of Poland. The efficiency models in these countries are therefore estimated using 2SLS with lagged values (of first to third order) of endogenous variables as instruments. Insignificant Sargan test statistics (cf. Table 5) indicate in all cases that the overidentifying restrictions are not rejected which suggests that selected instruments are orthogonal to the errors and therefore valid ${ }^{23}$. The relevance of selected instruments is assessed using the minimum eigenvalue statistic (Cragg and Donald, 1993) which in all cases rejects the null hypothesis of weak instruments. Note that using lagged explanatory variables as instruments only mitigates endogeneity in the case of no first-order autocorrelation in the residuals (e.g., Bellemare et al., 2017; Betz et al., 2018) and if lagged variables are themselves not relevant explanatory factors in the main equation (e.g., Reed, 2015). We, therefore, use the Arellano and Bond (1991) AR test which is particularly suited to detect autocorrelation in the residuals of 2SLS regressions. Table 5 indicates that the null hypothesis of no first-order autocorrelation is not rejected in any of the cases which confirms the adequateness of using lagged values as instruments. Moreover, following Mills and Schumann (1985) it appears reasonable to assume that lagged values of firm-specific factors should not be included in the main equation as firms at a given point in time choose between a flexible and efficient technology in relation to the current state of the firm ${ }^{24}$.

\footnotetext{
${ }^{23}$ Note that testing overidentifying restrictions is based on the assumption that at least one of the instruments is exogeneous (e.g. Wooldridge, 2006).

${ }^{24}$ E.g., some firms choose an efficient technology that leads to large production volumes (large firm size) while other firms choose a flexible but inefficient technology that leads to smaller firm size. Accordingly, we also do not interpret results as causal relationships but as conditional correlations.
} 
Finally, Variance Inflation Factors (VIFs) (cf. Table A4) are all smaller than 5, indicating that multicollinearity among the independent variables is not present in any of the models.

When interpreting the results for flexibility note that negative coefficients imply a positive relationship of the respective independent variable with flexibility and vice versa. In our interpretation, we focus on the overall patterns that both estimation strategies -i.e., fixed effects/2SLS and robust 0.5-quantile estimation- reveal. The results in Tables 4 and 5 provide evidence for a negative and significant relationship between firm size and flexibility (except for Poland) and a positive one between size and efficiency in France and Italy. Our findings hence mainly support Mills and Schumann`s (1985) hypothesis that larger firms benefit from higher efficiency while small firms can survive in the market due to advantages in flexibility (e.g., Renner et al., 2014).

Regarding firm age, the results provide evidence that increasing age leads to higher flexibility supporting our initial presumption that older firms benefit from their experience and a higher ability to adjust production capacities with increasing age (e.g., Renner et al., 2014). However, it has to be noted, that the results are somewhat inconclusive in the sense that the fixed effects estimations for Poland and Spain reveal a negative relationship between age and flexibility. It therefore also has to be considered that aging can lead to inertia, organizational rigidities, bureaucratic ossification, and reduced ability to react to changing economic circumstances (Majumdar 1997, Loderer and Waelchli 2010). With respect to efficiency and age, a negative correlation is detected for France and Italy which can be the result of employment of outdated capital, and resources as well as less advanced technology in older firms. In contrast, the positive age-efficiency relationship in Poland might be attributed to learning-by-doing effects (e.g., Hill and Kalirajan, 1993; Lundvall and Battese, 2000).

As regards the gearing ratio, our findings provide mixed evidence. In Italy, where a high average degree of gearing prevails we find a positive relationship with flexibility. Thus, in countries with high average gearing ratio, availability of outside financing may enable firms to invest and adapt production more easily. In the remaining countries, financial pressure associated with debt seems to reduce free cash flow and imposes restrictions on investment ultimately leading to lower flexibility (Chaddad and Mondelli 2013; Gschwandtner and Hirsch 2017). Also, gearing is positively related to efficiency in Italy and Poland indicating that liabilities can lead to a more thoughtful usage of resources in these countries. In turn, the negative relationship of gearing and efficiency in France and Spain is in line with Paul et al. (2000) who found that financial stress can impact the ability to maintain payments for variable inputs and cause adjustment problems that lead to reduced technical efficiency. Our results 
provide evidence for a negative relationship of capital intensity and flexibility (with the exception of France where capital intensity tends to enhance the adaptability of production capacities). Hence significant investments in fixed factors of production can lead to lower adaptability of production capacities and lower flexibility. Moreover, we find that capital intensity is negatively related to efficiency in most countries potentially caused by less efficient utilization of fixed capital and barriers to exit unprofitable activities.

Due to the special role of cooperatives in the EU dairy sector, we investigate whether these firms differ in their production flexibility and efficiency from IOFs including limited liability companies, one-person companies, and public companies. Table 4 reveals that in France and Spain cooperatives, as expected, are characterized by lower flexibility. This indicates that cooperatives are constrained to let each member provide its profit-maximizing quantity which in turn can lead to reduced flexibility in determining the optimal size (Soboh et al., 2011; 2012). Finally, the results reveal that cooperatives tend to operate less efficiently than IOFs potentially caused by higher costs of control, free rider problems, and less efficient utilization of inputs (Cook, 1995; Nilsson, 2001; Soboh et al., 2012).

Note that in each country unobserved factors influencing firms' technology choice will have an impact on both the Flex and efficiency equation implying that the error terms are correlated $^{25}$. However, a 3SLS approach which simultaneously accounts for endogenous variables and the system of seemingly unrelated regressions only leads to higher estimation efficiency in cases where different sets of regressors appear in both equations (Zellner, 1963). As there is no foundation to include different firm-specific variables in the Flex and efficiency equations, we abstain from using 3SLS.

\footnotetext{
${ }^{25}$ Based on a Breusch-Pagan test of independence, the null-hypothesis that this correlation is zero is rejected in all countries: France: corr. $=-0.0722,(p=0.001)$; Italy corr. $=-0.1997,(p=0.000)$; Poland: corr. $=-0.197,(p=0.000)$; Spain: corr. $=-0.233,(\mathrm{p}=0.000)$.
} 
Table 4. Drivers of flexibility

\begin{tabular}{|c|c|c|c|c|c|c|c|c|}
\hline \multirow[b]{2}{*}{ Variable } & \multicolumn{4}{|c|}{$\begin{array}{c}\text { Fixed effects (IV) estimation with adjusted } \\
\text { Flexibility }^{\mathrm{a}}\end{array}$} & \multicolumn{4}{|c|}{ Robust 0.5-quantile panel IV estimator ${ }^{b}$} \\
\hline & France & Italy & Poland & Spain & France & Italy & Poland & Spain \\
\hline Firm size & $\begin{array}{l}2.92 \mathrm{e}-6 * * * \\
(7.64 \mathrm{e}-7)\end{array}$ & $\begin{array}{c}2.93 \mathrm{e}-7 * * * \\
(9.78 \mathrm{e}-8)\end{array}$ & $\begin{array}{l}-4.27 \mathrm{e}-7 \\
(3.25 \mathrm{e}-7)\end{array}$ & $\begin{array}{l}-2.52 \mathrm{e}-7 \\
(1.79 \mathrm{e}-7)\end{array}$ & $\begin{array}{l}8.75 \mathrm{e}-8^{*} \\
(5.07 \mathrm{e}-8)\end{array}$ & $\begin{array}{l}1.12 \mathrm{e}-8^{*} \\
(6.33 \mathrm{e}-9)\end{array}$ & $\begin{array}{c}6.91 \mathrm{e}-8 \\
(8.53 \mathrm{e}-8)\end{array}$ & $\begin{array}{l}8.20 \mathrm{e}-8^{*} \\
(4.94 \mathrm{e}-8)\end{array}$ \\
\hline Firm age & $\begin{array}{c}-0.007 * * * \\
(0.001)\end{array}$ & $\begin{array}{c}-0.001 * * * \\
(0.000)\end{array}$ & $\begin{array}{c}0.001 * * \\
(4.35 \mathrm{e}-4)\end{array}$ & $\begin{array}{l}0.002 * \\
(0.001)\end{array}$ & $\begin{array}{l}-3.47 \mathrm{e}-4 * * * \\
(5.80 \mathrm{e}-5)\end{array}$ & $\begin{array}{l}-7.31 \mathrm{e}-5 * * * \\
(1.58 \mathrm{e}-5)\end{array}$ & $\begin{array}{l}-1.99 \mathrm{e}-5 \\
(1.71 \mathrm{e} 5)\end{array}$ & $\begin{array}{c}-0.002 * * * \\
(1.43 \mathrm{e}-4)\end{array}$ \\
\hline Gearing & $\begin{array}{c}4.89 \mathrm{e}-5 \\
(4.19 \mathrm{e}-5)\end{array}$ & $\begin{array}{l}2.73 \mathrm{e}-6 \\
(5.10 \mathrm{e}-6)\end{array}$ & $\begin{array}{l}1.08 \mathrm{e}-5 \\
(1.93 \mathrm{e}-5)\end{array}$ & $\begin{array}{l}3.64 \mathrm{e}-06 \\
(3.22 \mathrm{e}-5)\end{array}$ & $\begin{array}{l}1.63 \mathrm{e}-5 * * * \\
(5.57 \mathrm{e}-6)\end{array}$ & $\begin{array}{c}-3.21 \mathrm{e}-7 * * \\
(1.54 \mathrm{e}-7)\end{array}$ & $\begin{array}{l}6.26 e-6^{*} \\
(3.21 e-6)\end{array}$ & $\begin{array}{c}5.18 \mathrm{e}-5 * * * \\
(9.59 \mathrm{e}-6)\end{array}$ \\
\hline Capital intensity & $\begin{array}{l}1.54 \mathrm{e}-4 \\
(0.026)\end{array}$ & $\begin{array}{c}0.007 \\
(0.014)\end{array}$ & $\begin{array}{l}0.044 * * \\
(0.019)\end{array}$ & $\begin{array}{l}-0.002 \\
(0.026)\end{array}$ & $\begin{array}{c}-0.005 * * \\
(0.002)\end{array}$ & $\begin{array}{l}0.002 * * * \\
(3.34 \mathrm{e}-4)\end{array}$ & $\begin{array}{c}2.61 \mathrm{e}-5 \\
(2.72 \mathrm{e}-4)\end{array}$ & $\begin{array}{c}0.115^{* * *} \\
(0.015)\end{array}$ \\
\hline Cooperative & - & - & - & - & $\begin{array}{l}0.012^{*} \\
(0.007)\end{array}$ & $\begin{array}{c}0.001 \\
(0.001)\end{array}$ & $\begin{array}{c}4.63 \mathrm{e}-4 \\
(4.64 \mathrm{e}-4)\end{array}$ & $\begin{array}{c}0.216^{* * *} \\
(0.028)\end{array}$ \\
\hline Endogeneous variables ${ }^{\mathrm{c}}$ & None & None & None & None & None & None & None & None \\
\hline $\begin{array}{l}F \\
\text { p-value }\end{array}$ & $\begin{array}{l}18.28 \\
0.000\end{array}$ & $\begin{array}{l}11.69 \\
0.000\end{array}$ & $\begin{array}{c}1.56 \\
0.186\end{array}$ & $\begin{array}{c}0.79 \\
0.530\end{array}$ & & & & \\
\hline $\begin{array}{l}\text { Hausmann test } \\
\text { Chi }^{2} \\
\text { p-value }\end{array}$ & $\begin{array}{l}10.71 \\
0.030\end{array}$ & $\begin{array}{l}15.11 \\
0.002\end{array}$ & $\begin{array}{l}41.34 \\
0.000\end{array}$ & $\begin{array}{l}17.38 \\
0.001\end{array}$ & & & & \\
\hline \# obs. & 2,134 & 5,314 & 321 & 2,048 & 2,182 & 5,462 & 333 & 2,122 \\
\hline
\end{tabular}

endogeneity (Table A3). Standard errors in parentheses. ${ }^{* * *}, * *,{ }^{*}$ significant at the $1 \%, 5 \%, 10 \%$ level respectively. 
Table 5. Drivers of technical efficiency

\begin{tabular}{|c|c|c|c|c|c|c|c|c|}
\hline \multirow[b]{2}{*}{ Variable } & \multicolumn{4}{|c|}{ Fixed effects (IV) estimation } & \multicolumn{4}{|c|}{ Robust 0.5-quantile panel IV estimator } \\
\hline & France & Italy & Poland & Spain & France & Italy & Poland & Spain \\
\hline Firm size & $\begin{array}{l}2.66 \mathrm{e}-9 \\
(1.13 \mathrm{e}-7)\end{array}$ & $\begin{array}{l}3.10 \mathrm{e}-7 * * \\
(1.41 \mathrm{e}-7)\end{array}$ & $\begin{array}{c}4.08 \mathrm{e}-10 \\
(3.06 \mathrm{e}-10)\end{array}$ & $\begin{array}{l}-3.14 \mathrm{e}-8 \\
(8.01 \mathrm{e}-8)\end{array}$ & $\begin{array}{l}7.26 \mathrm{e}-8 * * * \\
(1.96 \mathrm{e}-8)\end{array}$ & $\begin{array}{c}4.79 \mathrm{e}-8 * * * \\
(4.50 \mathrm{e}-9)\end{array}$ & $\begin{array}{c}8.01 \mathrm{e}-11 \\
(6.48 \mathrm{e}-11)\end{array}$ & $\begin{array}{c}6.98 \mathrm{e}-8 \\
(2.75 \mathrm{e}-7)\end{array}$ \\
\hline Firm age & $\begin{array}{l}-2.26 \mathrm{e}-4 \\
(1.51 \mathrm{e}-4)\end{array}$ & $\begin{array}{l}-2.86 \mathrm{e}-4 \\
(2.94 \mathrm{e}-4)\end{array}$ & $\begin{array}{l}2.29 \mathrm{e}-7 \\
(5.29 \mathrm{e}-7)\end{array}$ & $\begin{array}{c}3.00 \mathrm{e}-4 \\
(4.06 \mathrm{e}-4)\end{array}$ & $\begin{array}{l}-4.62 e-4 * * * \\
(2.47 e-5)\end{array}$ & $\begin{array}{l}-2.60 \mathrm{e}-5^{* * *} \\
(1.55 \mathrm{e}-6)\end{array}$ & $\begin{array}{l}4.08 \mathrm{e}-8 * * * \\
(1.52 \mathrm{e}-8)\end{array}$ & $\begin{array}{c}0.001 \\
(0.003)\end{array}$ \\
\hline Gearing & $\begin{array}{l}1.12 \mathrm{e}-5 \\
(9.79 \mathrm{e}-6)\end{array}$ & $\begin{array}{l}-2.03 e-5 \\
(2.65 e-5)\end{array}$ & $\begin{array}{l}-3.17 \mathrm{e}-9 \\
(4.00 \mathrm{e}-8)\end{array}$ & $\begin{array}{l}-1.35 \mathrm{e}-5 \\
(1.73 \mathrm{e}-5)\end{array}$ & $\begin{array}{l}-1.40 \mathrm{e}-5^{* * *} \\
(1.29 \mathrm{e}-6)\end{array}$ & $\begin{array}{l}1.93 \mathrm{e}-06^{* * *} \\
(1.59 \mathrm{e}-7)\end{array}$ & $\begin{array}{c}6.81 \mathrm{e}-09^{* * *} \\
(7.70 \mathrm{e}-10)\end{array}$ & $\begin{array}{r}-1.13 \mathrm{e}-5^{*} \\
(6.20 \mathrm{e}-6)\end{array}$ \\
\hline Capital intensity & $\begin{array}{l}-0.015 * * * \\
(0.004)\end{array}$ & $\begin{array}{l}-0.028 \\
(0.019)\end{array}$ & $\begin{array}{l}2.16 \mathrm{e}-5 \\
(3.20 \mathrm{e}-5)\end{array}$ & $\begin{array}{c}-0.025^{* *} \\
(0.012)\end{array}$ & $\begin{array}{c}-0.003 * * * \\
(0.001)\end{array}$ & $\begin{array}{c}-0.012 * * * \\
(1.64 \mathrm{e}-4)\end{array}$ & $\begin{array}{c}2.35 \mathrm{e}-07 \\
(2.19 \mathrm{e}-06)\end{array}$ & $\begin{array}{l}-0.009 \\
(0.013)\end{array}$ \\
\hline Cooperative & - & - & - & - & $\begin{array}{c}-0.002 * * * \\
(0.000)\end{array}$ & $\begin{array}{c}-0.003 * * * \\
(9.55 \mathrm{e}-5)\end{array}$ & $\begin{array}{l}-5.82 \mathrm{e}-06^{* * * *} \\
(1.62 \mathrm{e}-06)\end{array}$ & $\begin{array}{l}0.0421 \\
(0.094)\end{array}$ \\
\hline $\begin{array}{l}\text { Endogeneous variables }{ }^{\mathrm{a}} \\
\text { Instruments used (lags) }\end{array}$ & $\begin{array}{c}\text { Gearing } \\
1-3\end{array}$ & $\begin{array}{c}\text { Gearing } \\
2-3\end{array}$ & $\begin{array}{l}\text { Cap. Int. } \\
1-2\end{array}$ & None & $\begin{array}{c}\text { Gearing } \\
1-3\end{array}$ & $\begin{array}{c}\text { Gearing } \\
2-3\end{array}$ & $\begin{array}{l}\text { Cap. Int. } \\
1-2\end{array}$ & None \\
\hline $\begin{array}{l}\mathrm{F} \\
\mathrm{p} \text {-value }\end{array}$ & $\begin{array}{l}3.880 \\
0.004\end{array}$ & $\begin{array}{l}5.450 \\
0.000\end{array}$ & $\begin{array}{l}0.570 \\
0.682\end{array}$ & $\begin{array}{l}2.800 \\
0.025\end{array}$ & & & & \\
\hline $\begin{array}{l}\text { Hausmann test } \\
\text { Chi }^{2} \\
\text { p-value }\end{array}$ & $\begin{array}{c}6.58 \\
0.087\end{array}$ & $\begin{array}{l}14.11 \\
0.003\end{array}$ & $\begin{array}{c}5.07 \\
0.167\end{array}$ & $\begin{array}{c}1.88 \\
0.598\end{array}$ & & & & \\
\hline $\begin{array}{l}\text { First-stage statistics } \\
\text { Minimum eigenvalue statistic } \\
\text { Critical value } \\
\text { Arellano and Bond AR(1) }\end{array}$ & $\begin{array}{c}39.643 \\
5.39\end{array}$ & $\begin{array}{c}16.525 \\
7.25\end{array}$ & $\begin{array}{c}20.814 \\
7.25\end{array}$ & & & & & \\
\hline $\begin{array}{l}\mathrm{z} \\
\text { p-value } \\
\text { Sargan } \mathrm{Chi}^{2} \\
\text { p-value }\end{array}$ & $\begin{array}{c}0.97 \\
0.332 \\
2.312 \\
0.315\end{array}$ & $\begin{array}{c}0.89 \\
0.375 \\
1.768 \\
0.184\end{array}$ & $\begin{array}{c}-0.90 \\
(0.369) \\
2.297 \\
0.130\end{array}$ & & & & & \\
\hline \# obs. & 1.049 & 3,014 & 180 & 2,094 & 2,182 & 5,462 & 333 & 2,122 \\
\hline
\end{tabular}

Note: Dependent variable: technical efficiency. Standard errors in parentheses. $* * * * * *$ significant at the 1\%, 5\%, 10\% level respectively a Based on Davidson-MacKinnon test for endogeneity (Table A3). ${ }^{\mathrm{b}}$ Based on Minimum eigenvalue criterion, Arellano and Bond test for autocorrelation and Sargan test of overidentifying restrictions 


\subsection{Flexibility in times of economic crisis}

Finally, we assess how far production flexibility enables firms to sustain profitability during the economic crisis $2008-2009^{26}$ based on the dynamic panel model specified by equation (10).

The results in Table 6 confirm the findings of previous studies that focus on the drivers of profitability in the food sector. In particular, profitability tends to persist over time (as indicated by the positive and significant impact of lagged profitability in all cases), the negative impact of financial risk (gearing), and the positive impact of technical efficiency (e.g., Morrison Paul et al., 2004; Hirsch and Gschwandtner, 2013). In addition, we find a positive impact of firm age in Poland, likely due to experience effects. Additionally, we find a negative effect of size and capital intensity in the case of France pointing towards diseconomies of scale. Our findings are consistent with Goddard et al. (2005). Regarding legal form in the majority of countries, cooperatives are characterized by lower profitability, compared to IOFs. For example, Soboh et al. (2009) show that while cooperatives have to cope with the competitive market environment like other firms, they are not necessarily profit-oriented as they aim to pay to their members the highest possible price while ensuring the viability of the cooperative. This can imply that cooperatives push the price they pay to their members to the point where profit is zero (Novkovic 2008, Hirsch and Hartmann 2014).

We now turn our attention to the main coefficients of interest, namely those that measure the impact of flexibility on profitability during an economic crisis. In general, the results reveal that the economic crisis only had a significant negative impact on profitability in Italy and Poland. These results are consistent with previous findings that the food industry is a rather crisis-proof sector, which is less strongly affected by the business cycle than other manufacturing sectors due to stable demand for food products (Lienhardt 2004; FoodDrink Europe 2011; Hirsch 2014). Regarding flexibility, note that a negative coefficient of the Flex measure indicates that profitability increases with flexibility while positive coefficients imply that flexibility and profitability are negatively related. The interaction term of Flex and the crisis dummy $\left(d_{c}\right)$ in Table 6 reveals that in the case of France and Italy flexibility leads to higher profitability during the economic crisis. Recall that in the case of French dairy flexibility also has a positive impact on profitability in general. We, therefore, calculate the marginal effects of flexibility on profitability during and outside the economic crisis and assess whether both values differ significantly. The values can be found in the lower panel of Table 6 and indicate

\footnotetext{
${ }^{26}$ The EU dairy processing sector was hit by the economic crisis between 2008 and 2010 while 2011 turnover exceeded pre-crisis (2007) levels. An exception is Poland where already in 2010 turnover exceeds the 2007 level Eurostat (2017).
} 
that both in France and in Italy the impact of flexibility is significantly larger during the time of economic crisis, compared to the estimates on flexibility outside the crisis period.

Table 6. Profitability and flexibility in times of economic crisis

\begin{tabular}{|c|c|c|c|c|}
\hline Variable & France & Italy & Poland & Spain \\
\hline$R O A_{i, t-1}$ & $\begin{array}{c}0.319 * * * \\
(0.003)\end{array}$ & $\begin{array}{c}0.098^{* *} \\
(0.049)\end{array}$ & $\begin{array}{c}0.133^{* *} \\
(0.061)\end{array}$ & $\begin{array}{l}0.219^{*} \\
(0.115)\end{array}$ \\
\hline Crisis $\left(d_{c}\right)$ & $\begin{array}{c}0.003 \\
(0.005)\end{array}$ & $\begin{array}{c}-0.007 * * \\
(0.003)\end{array}$ & $\begin{array}{c}-0.035^{*} \\
(0.019)\end{array}$ & $\begin{array}{c}-0.023 \\
(0.023)\end{array}$ \\
\hline Flex & $\begin{array}{c}-0.009^{* * *} \\
(0.002)\end{array}$ & $\begin{array}{c}-0.002 \\
(0.002)\end{array}$ & $\begin{array}{c}0.430 \\
(0.305)\end{array}$ & $\begin{array}{c}-1.93 \mathrm{e}-4 \\
(0.002)\end{array}$ \\
\hline Flex*Crisis & $\begin{array}{c}-0.014 * * * \\
(0.002)\end{array}$ & $\begin{array}{c}-0.034^{*} \\
(0.019)\end{array}$ & $\begin{array}{c}-0.574 \\
(0.355)\end{array}$ & $\begin{array}{c}0.002 \\
(0.003)\end{array}$ \\
\hline Technical efficiency & $\begin{array}{c}1.722 * * * \\
(0.075)\end{array}$ & $\begin{array}{c}2.618 * * * \\
(0.358)\end{array}$ & $\begin{array}{c}0.259 * * \\
(0.111)\end{array}$ & $\begin{array}{c}1.043 * * \\
(0.498)\end{array}$ \\
\hline Firm size & $\begin{array}{c}-0.014 * * * \\
(0.002)\end{array}$ & $\begin{array}{c}-0.003 \\
(0.013)\end{array}$ & $\begin{array}{l}-0.016 \\
(0.014)\end{array}$ & $\begin{array}{l}-0.004 \\
(0.011)\end{array}$ \\
\hline Firm age & $\begin{array}{c}1.13 \mathrm{e}-4 \\
(1.32 \mathrm{e}-4)\end{array}$ & $\begin{array}{l}-1.74 \mathrm{e}-4 \\
(4.31 \mathrm{e}-4)\end{array}$ & $\begin{array}{c}0.001^{*} \\
(3.09 \mathrm{e}-4)\end{array}$ & $\begin{array}{c}0.001 \\
(0.001)\end{array}$ \\
\hline Gearing & $\begin{array}{c}-2.79 e-5 * \\
(1.49 e-5)\end{array}$ & $\begin{array}{c}-1.52 \mathrm{e}-4 * * * \\
(3.68 \mathrm{e}-5)\end{array}$ & $\begin{array}{c}-0.001 * * * \\
(2.45 \mathrm{e}-4)\end{array}$ & $\begin{array}{c}0.000 * * \\
(0.000)\end{array}$ \\
\hline Capital intensity & $\begin{array}{c}-0.038^{* * *} \\
(0.011)\end{array}$ & $\begin{array}{c}-0.005 \\
(0.038)\end{array}$ & $\begin{array}{c}0.084 \\
(0.090)\end{array}$ & $\begin{array}{c}-0.021 \\
(0.049)\end{array}$ \\
\hline Cooperative & $\begin{array}{c}-0.017 * * * \\
(0.006)\end{array}$ & $\begin{array}{c}-0.008 \\
(0.011)\end{array}$ & $\begin{array}{c}-0.135^{* * *} \\
(0.027)\end{array}$ & $\begin{array}{c}-0.108 * * * \\
(0.036)\end{array}$ \\
\hline \# obs. & 1,865 & 4,850 & 288 & 1,992 \\
\hline Wald $\chi^{2}$ & $28695.290 * * *$ & $218.360 * * *$ & $3285.220 * * *$ & $91.45 * * *$ \\
\hline $\begin{array}{l}\operatorname{AR}(2) z \\
\mathrm{p} \\
\text { Hansen } \chi^{2} \\
\mathrm{p}\end{array}$ & $\begin{array}{c}-0.520 \\
0.603 \\
166.710 \\
0.127\end{array}$ & $\begin{array}{c}-0.720 \\
0.469 \\
63.560 \\
0.111\end{array}$ & $\begin{array}{c}1.870 \\
0.061 \\
26.560 \\
0.148\end{array}$ & $\begin{array}{c}0.030 \\
0.977 \\
15.180 \\
0.232\end{array}$ \\
\hline \multicolumn{5}{|c|}{ Marginal impact of Flex } \\
\hline During crisis & $\begin{array}{c}-0.024 * * * \\
(0.003)\end{array}$ & $\begin{array}{c}-0.036^{*} \\
(0.019)\end{array}$ & $\begin{array}{c}-0.144 \\
(0.161)\end{array}$ & $\begin{array}{c}0.002 \\
(0.003)\end{array}$ \\
\hline Outside crisis & $\begin{array}{c}-0.009 * * * \\
(0.002)\end{array}$ & $\begin{array}{c}-0.002 \\
(0.002)\end{array}$ & $\begin{array}{c}0.430 \\
(0.305)\end{array}$ & $\begin{array}{l}-0.000 \\
(0.002)\end{array}$ \\
\hline Difference & $\begin{array}{c}-0.014 * * * \\
(0.002)\end{array}$ & $\begin{array}{c}-0.034^{*} \\
(0.019)\end{array}$ & $\begin{array}{c}-0.574 \\
(0.355)\end{array}$ & $\begin{array}{c}0.002 \\
(0.003)\end{array}$ \\
\hline
\end{tabular}

Note: Dependent variable: return on assets $\left(R O A_{i, t}\right)$; Standard errors in parentheses.

$* * *, * *, *$ significant at the $1 \%, 5 \%, 10 \%$ level respectively.

Results are generated using Arellano and Bond`s (1991) GMM estimator

It is important to note that for all models VIFs are below the threshold of 5 (cf. Table A4). This indicates that despite the above confirmed relationship between flexibility and efficiency including both measures in a single model does not cause critical levels of multicollinearity ${ }^{27}$. Moreover, the Wald test confirms the overall significance of all models, and

\footnotetext{
${ }^{27}$ Only for Spain severe multicollinearity between Flex and Flex* $\mathrm{d}_{\mathrm{c}}$ is detected. We therefore present VIFs excluding Flex $* d_{c}$ in this case.
} 
in all cases, second-order serial correlation is not detected. Finally, the Hansen statistics of overidentifying restrictions remain insignificant (Table 6), implying that instruments have been adequately implemented.

\section{Conclusions}

In this article, we measured firms` ability to adapt to fluctuating economic conditions using a flexibility index based on input-distance functions. Such analysis can be particularly crucial for decision makers in sectors, such as the EU dairy processing industry, characterized by strong fluctuations in market environments.

Our analysis revealed that production flexibility in the EU dairy processing industry varies significantly across countries. For instance, higher flexibility prevails in Italy and Poland while production in Spain tends to be less flexible. In line with the "theory of industry structure with fluctuating demand", we find that small firms tend to be more flexible implying that these firms can coexist with large firms in the market. Furthermore, we found a tradeoff between flexibility and technical efficiency that mainly affects larger dairy processing firms implying that a sole focus on firm efficiency can be insufficient. For small firms, the tradeoff between efficiency and flexibility is potentially mitigated because these firms can exploit market power in niche markets. Unfortunately, the industry classification in our dataset does not allow us to identify further the subsector (e.g., cheese or fluid milk manufacturing) that individual firms operate in. Moreover, the majority of firms are likely to be active in a larger number of subsectors. As a result, we cannot clearly identify the impact that industry concentration has on the tradeoff between efficiency and flexibility.

Decision makers should be cognizant of the effects that investments in fixed production factors, financial liability or organizational rigidities and bureaucratic ossification can have on a firm`s efficiency and its ability to handle demand fluctuations. Recent developments in the EU dairy sector such as the abolition of the quota system have triggered a debate on the competitiveness of cooperatives. In line with previous literature, we find evidence that cooperatives in the EU dairy sector are characterized by lower efficiency. With respect to flexibility, we find that cooperatives in the case of France and Spain tend to have a lower capacity to adapt output, compared to IOFs potentially due to their organizational structure and obligations to members.

An application of our results to firm profitability in times of economic crisis revealed that in France and Italy production flexibility may be an important factor in sustaining firm 
performance for dairy processors. However, one needs to exercise caution when interpreting these findings because our dataset only comprises of firms with complete data over the period analyzed. This implies that firms that went bankrupt during the economic crisis period are not considered which could lead to an upward bias of ROA and could explain the overall insignificant impact of the economic crisis in France and Spain. It is also likely that firms survived the economic downturn because of production flexibility leading to a mitigation of the impact of flexibility on profitability. Unfortunately, our data do not allow us to compare the flexibility of firms that exited the market with those that managed to stay in the market during the economic crisis (2008-2010). Moreover, our analysis is based on a highly aggregated scope of the economic crisis. Hence, to derive more detailed management implications, further research should include a more disaggregated application of the results to a smaller set of firms that are affected by local economic crisis or food-related incidents.

Nevertheless, our findings can help to promote the economic viability of food industry firms in times of economic crisis and can thus be beneficial for the economic sustainability of the food manufacturing sector and the functioning of the food value chain as a whole. 


\section{Appendix}

Table A1. Input-distance functions estimation results

\begin{tabular}{|c|c|c|c|c|}
\hline Variable & France & Italy & Poland & Spain \\
\hline \multirow[t]{2}{*}{ Constant } & $1.287 * * *$ & $1.370 * * *$ & $1.094 * * *$ & $1.269 * * *$ \\
\hline & $(0.012)$ & $(0.015)$ & $(0.044)$ & $(0.027)$ \\
\hline \multirow[t]{2}{*}{$\mathrm{y}$} & $-1.126^{* * *}$ & $-1.051 * * *$ & $-0.959 * * *$ & $-1.045^{* * *}$ \\
\hline & $(0.006)$ & $(0.009)$ & $(0.027)$ & $(0.009)$ \\
\hline \multirow[t]{2}{*}{$\mathrm{x}_{2}$} & $0.484 * * *$ & $0.412^{* * *}$ & $0.386^{* * *}$ & $0.443 * * *$ \\
\hline & $(0.006)$ & $(0.005)$ & $(0.017)$ & $(0.006)$ \\
\hline \multirow[t]{2}{*}{$\mathrm{k}$} & $0.049 * * *$ & $0.047 * * *$ & $-0.034^{*}$ & $0.045^{* * *}$ \\
\hline & $(0.004)$ & $(0.005)$ & $(0.018)$ & $(0.006)$ \\
\hline \multirow[t]{2}{*}{$y^{*} y$} & $0.048 * * *$ & $0.023 * * *$ & $0.031 * *$ & -0.005 \\
\hline & $(0.003)$ & $(0.004)$ & $(0.012)$ & $(0.006)$ \\
\hline \multirow[t]{2}{*}{$\mathrm{x}_{2} * \mathrm{x}_{2}$} & $0.199 * * *$ & $0.141^{* * * *}$ & $0.196^{* * *}$ & $0.160 * * *$ \\
\hline & $(0.003)$ & $(0.002)$ & $(0.008)$ & $(0.004)$ \\
\hline \multirow[t]{2}{*}{$\mathrm{k} * \mathrm{k}$} & $0.003 * *$ & $0.008 * * *$ & $0.031^{* * *}$ & 0.001 \\
\hline & $(0.001)$ & $(0.002)$ & $(0.007)$ & $(0.003)$ \\
\hline \multirow[t]{2}{*}{$\mathrm{x}_{2} * \mathrm{y}$} & $-0.035^{* * *}$ & 0.002 & $-0.043 * * *$ & $0.015^{* * *}$ \\
\hline & $(0.003)$ & $(0.002)$ & $(0.008)$ & $(0.004)$ \\
\hline \multirow[t]{2}{*}{$\mathrm{k}^{*} \mathrm{y}$} & $-0.011 * * *$ & $-0.012 * * *$ & $-0.030 * * *$ & 0.006 \\
\hline & $(0.001)$ & $(0.002)$ & $(0.008)$ & $(0.004)$ \\
\hline \multirow[t]{2}{*}{$\mathrm{x} 2 * \mathrm{k}$} & $0.009 * * *$ & $-0.005 * * *$ & $0.043 * * *$ & $-0.023 * * *$ \\
\hline & $(0.002)$ & $(0.002)$ & $(0.005)$ & $(0.003)$ \\
\hline \multirow[t]{2}{*}{ t07 } & $-0.039 * * *$ & 0.004 & -0.016 & -0.005 \\
\hline & $(0.011)$ & $(0.012)$ & $(0.022)$ & $(0.032)$ \\
\hline \multirow[t]{2}{*}{ t08 } & $-0.025 * *$ & $-0.045 * * *$ & 0.019 & -0.011 \\
\hline & $(0.011)$ & $(0.012)$ & $(0.022)$ & $(0.026)$ \\
\hline \multirow[t]{2}{*}{ t09 } & $0.089 * * *$ & -0.001 & 0.033 & -0.019 \\
\hline & $(0.011)$ & $(0.012)$ & $(0.022)$ & $(0.026)$ \\
\hline \multirow[t]{2}{*}{$\mathrm{t} 10$} & $0.032 * * *$ & $-0.026^{* *}$ & $0.063^{* * *}$ & -0.023 \\
\hline & $(0.011)$ & $(0.012)$ & $(0.022)$ & $(0.026)$ \\
\hline \multirow[t]{2}{*}{$\mathrm{t} 11$} & 0.004 & $-0.070 * * *$ & -0.003 & -0.041 \\
\hline & $(0.011)$ & $(0.012)$ & $(0.022)$ & $(0.026)$ \\
\hline \multirow[t]{2}{*}{$\mathrm{t} 12$} & $0.037 * * *$ & -0.018 & 0.027 & -0.026 \\
\hline & $(0.011)$ & $(0.012)$ & $(0.022)$ & $(0.026)$ \\
\hline \multirow[t]{2}{*}{$\mathrm{t} 13$} & -0.002 & $-0.037 * * *$ & 0.016 & -0.035 \\
\hline & $(0.011)$ & $(0.012)$ & $(0.022)$ & $(0.026)$ \\
\hline \multirow[t]{2}{*}{$\mathrm{t} 14$} & $-0.023 * *$ & $-0.034 * * *$ & $0.058 * *$ & $-0.053 * *$ \\
\hline & $(0.012)$ & $(0.012)$ & $(0.023)$ & $(0.026)$ \\
\hline
\end{tabular}

Tests for conditions of monotonicity and concavity

(Shares of consistent results with elasticities at sample mean in parentheses)

$\begin{array}{lcccc}\text { Non-decreasing in x1 } & 0.983 & 0.969 & 0.926 & 0.983 \\ & (0.368) & (0.343) & (0.218) & (0.340) \\ \text { Non-decreasing in x2 } & 0.980 & 0.995 & 0.995 & 0.995 \\ & (0.632) & (0.657) & (0.782) & (0.660) \\ \text { Non-increasing in k } & 0.016 & 0.205 & 0.247 & 0.044 \\ & (0.033) & (0.013) & (0.023) & (0.030) \\ \text { Non-increasing in y } & 1 & 1 & 1 & 1 \\ & (-1.043) & (-0.995) & (-1.008) & (-1.028) \\ \text { Concavity } & 0.605 & 0.883 & 0.374 & 0.784 \\ \text { Model diagnostics } & & & & \\ \text { Log L } & & & & \\ \text { Wald } \chi^{2} & 1,480.223 & 52.424 & 415.375 & 911.352 \\ \text { p } & 330,337.07 & 274,353.84 & 68,948.94 & 227,031.29 \\ \text { sigma_u } & 0.000 & 0.000 & 0.000 & 0.000 \\ & 1.630^{* * *} & 2.626^{* * *} & 0.024 & 1.719 \\ \text { sigma_v } & (0.558) & (0.016) & (0.504) & (1.129) \\ & 0.154 * * * & 0.218^{* * *} & 0.165 * * * & 0.149 * * * \\ \text { Lambda } & (0.002) & (0.001) & (0.004) & (0.003) \\ & 10.575 * * * & 12.029^{* * *} & 0.147 & 11.505^{* * *} \\ \text { \# obs. } & (0.558) & (0.016) & (0.504) & (1.130) \\ & 3,987 & 7,319 & 1,087 & 3,038\end{array}$

Note: Standard errors in parentheses. ${ }^{* * *}, * *, *$ significant at the $1 \%, 5 \%, 10 \%$ level For variable definitions see sections 3.1 and 4 . 
Table A2. Mean flexibility and technical efficiency (2006-2014)

\begin{tabular}{lcccc} 
& France & Italy & Poland & Spain \\
\hline Flex & 0.0997 & 0.0194 & 0.0044 & 0.0966 \\
& $(0.3120)$ & $(0.0966)$ & $(0.0154)$ & $(0.2068)$ \\
Technical Efficiency & 0.9424 & 0.9171 & & \\
& $(0.0281)$ & $(0.0314)$ & $(0.0991$ & 0.9093 \\
& & & & $(0.0522)$
\end{tabular}

Notes: Flex adjusted for Flex adjusted for top and bottom 1\% of observations. Standard deviations in parentheses.

Table A3. Davidson-MacKinnon Test for endogeneity

\begin{tabular}{|c|c|c|c|c|}
\hline Variable & France & Italy & Poland & Spain \\
\hline \multicolumn{5}{|l|}{ Flex equation } \\
\hline Firm size & $\begin{array}{c}0.015 \\
(0.902)\end{array}$ & $\begin{array}{c}0.256 \\
(0.613)\end{array}$ & $\begin{array}{c}0.088 \\
(0.766)\end{array}$ & $\begin{array}{c}0.121 \\
(0.728)\end{array}$ \\
\hline Gearing & $\begin{array}{c}0.524 \\
(0.469)\end{array}$ & $\begin{array}{c}0.099 \\
(0.753)\end{array}$ & $\begin{array}{c}0.222 \\
(0.637)\end{array}$ & $\begin{array}{c}0.458 \\
(0.499)\end{array}$ \\
\hline Capital intensity & $\begin{array}{c}2.068 \\
(0.150)\end{array}$ & $\begin{array}{c}1.602 \\
(0.206)\end{array}$ & $\begin{array}{c}0.265 \\
(0.607)\end{array}$ & $\begin{array}{c}1.531 \\
(0.216)\end{array}$ \\
\hline Joint & $\begin{array}{c}1.169 \\
(0.321)\end{array}$ & $\begin{array}{c}0.558 \\
(0.643)\end{array}$ & $\begin{array}{c}0.463 \\
(0.709)\end{array}$ & $\begin{array}{c}0.735 \\
(0.531)\end{array}$ \\
\hline \multicolumn{5}{|l|}{ TE equation } \\
\hline Firm size & $\begin{array}{c}0.001 \\
(0.970)\end{array}$ & $\begin{array}{c}0.112 \\
(0.737)\end{array}$ & $\begin{array}{c}0.727 \\
(0.394)\end{array}$ & $\begin{array}{c}0.024 \\
(0.878)\end{array}$ \\
\hline Gearing & $\begin{array}{c}5.376^{* *} \\
(0.020)\end{array}$ & $\begin{array}{l}3.197 * \\
(0.074)\end{array}$ & $\begin{array}{c}0.005 \\
(0.946)\end{array}$ & $\begin{array}{c}0.419 \\
(0.518)\end{array}$ \\
\hline Capital intensity & $\begin{array}{c}0.725 \\
(0.395)\end{array}$ & $\begin{array}{c}2.644 \\
(0.104)\end{array}$ & $\begin{array}{c}33.171 * * * \\
(0.000)\end{array}$ & $\begin{array}{c}0.201 \\
(0.653)\end{array}$ \\
\hline Joint & $\begin{array}{c}1.817 \\
(0.1422)\end{array}$ & $\begin{array}{l}2.482^{*} \\
(0.059)\end{array}$ & $\begin{array}{c}12.880 * * * \\
(0.000)\end{array}$ & $\begin{array}{c}0.194 \\
(0.901)\end{array}$ \\
\hline
\end{tabular}

Note: Nullhypothesis of exogeneity. $\mathrm{Chi}^{2}$ ( $\mathrm{p}$-value); $\mathrm{F}$ (p-value) for joint test parentheses. $* * *, * *, *$ significant at the $1 \%, 5 \%, 10 \%$ level respectively. 
Table A4. Variance Inflation Factors (VIFs)

\begin{tabular}{|c|c|c|c|c|c|c|c|c|c|c|c|c|}
\hline Variable & Fr & It & Pl & Sp & Fr & It & PI & Sp & Fr & It & PI & Sp \\
\hline & \multicolumn{4}{|c|}{ Drivers of flexibility } & \multicolumn{4}{|c|}{$\begin{array}{c}\text { Drivers of technical } \\
\text { efficiency }\end{array}$} & \multicolumn{4}{|c|}{ Profitability analysis } \\
\hline Firm size & 1.09 & 1.08 & 1.06 & 1.05 & 1.07 & 1.03 & 1.06 & 1.02 & 1.33 & 1.24 & 1.29 & 1.19 \\
\hline Firm age & 1.12 & 1.77 & 1.35 & 1.16 & 1.11 & 1.68 & 1.35 & 1.13 & 1.26 & 1.90 & 1.44 & 1.34 \\
\hline Gearing & 1.17 & 1.03 & 1.09 & 1.09 & 1.17 & 1.02 & 1.09 & 1.08 & 1.21 & 1.05 & 1.15 & 1.10 \\
\hline Capital intensity & 1.14 & 1.03 & 1.07 & 1.08 & 1.14 & 1.03 & 1.08 & 1.09 & 1.16 & 1.11 & 1.14 & 1.11 \\
\hline Technical efficiency & - & - & - & - & - & - & - & - & 1.11 & 1.12 & 1.21 & 1.24 \\
\hline Flex & - & - & - & - & - & - & - & - & 1.48 & 1.58 & 2.59 & 1.15 \\
\hline Cooperative & 1.09 & 1.72 & 1.53 & 1.04 & 1.08 & 1.67 & 1.53 & 1.04 & 1.08 & 1.75 & 1.97 & 1.04 \\
\hline$R O A_{i, t-1}$ & - & - & - & - & - & - & - & - & 1.13 & 1.12 & 1.28 & 1.12 \\
\hline$d_{c}$ & - & - & - & - & - & - & - & - & 1.05 & 1.01 & 1.08 & 1.04 \\
\hline Flex*Crisis & - & - & - & - & - & - & - & - & 1.41 & 1.49 & 2.41 & - \\
\hline Mean VIF & 1.12 & 1.32 & 1.22 & 1.09 & 1.12 & 1.29 & 1.22 & 1.07 & 1.22 & 1.34 & 1.56 & 1.15 \\
\hline
\end{tabular}

Note: Calculated based on OLS regressions 

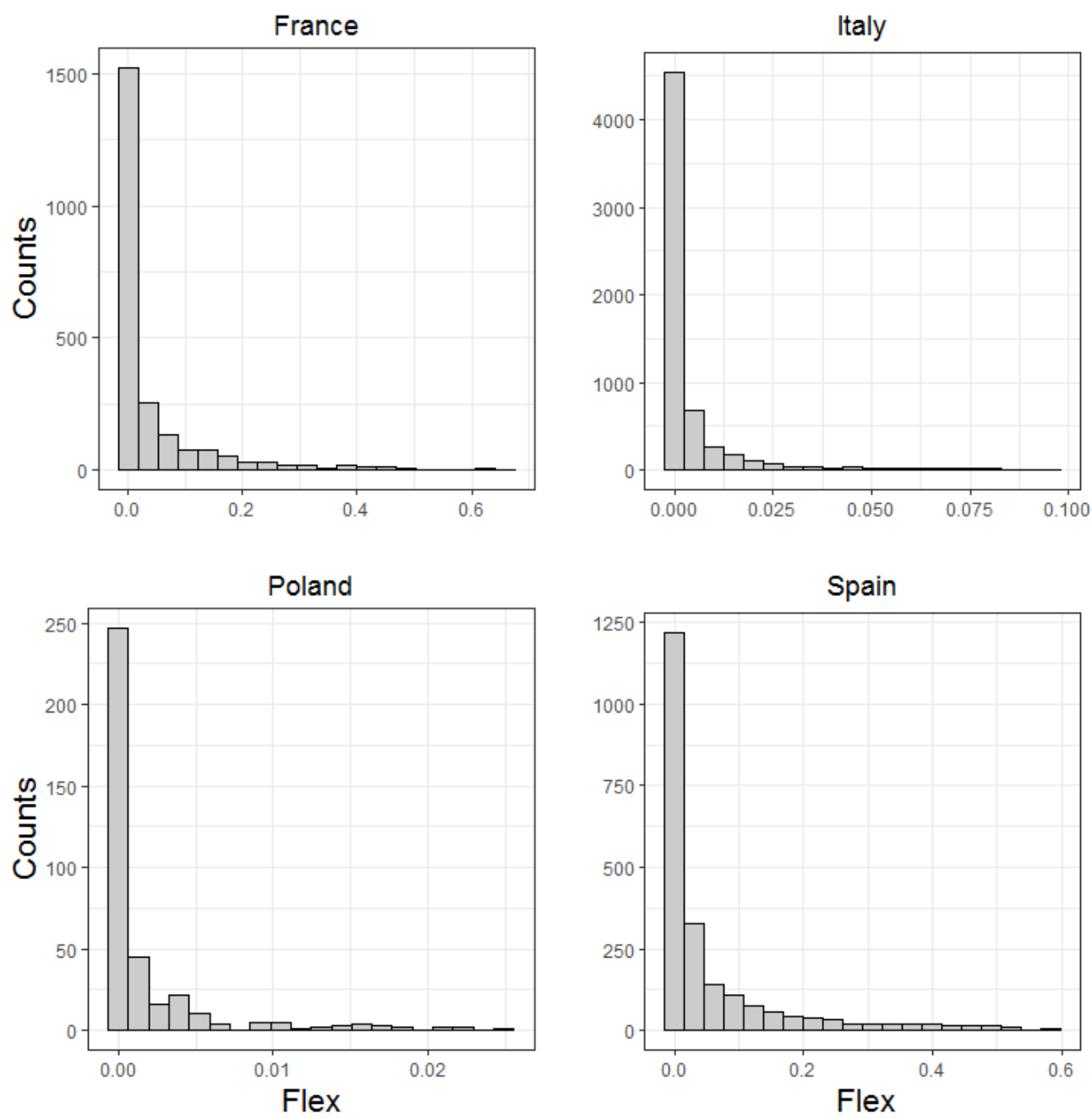

Figure A1. Distribution of flexibility by country

Notes: Displayed firm-size ranges are $90 \%$-quantiles of flexibility 


\section{Small}
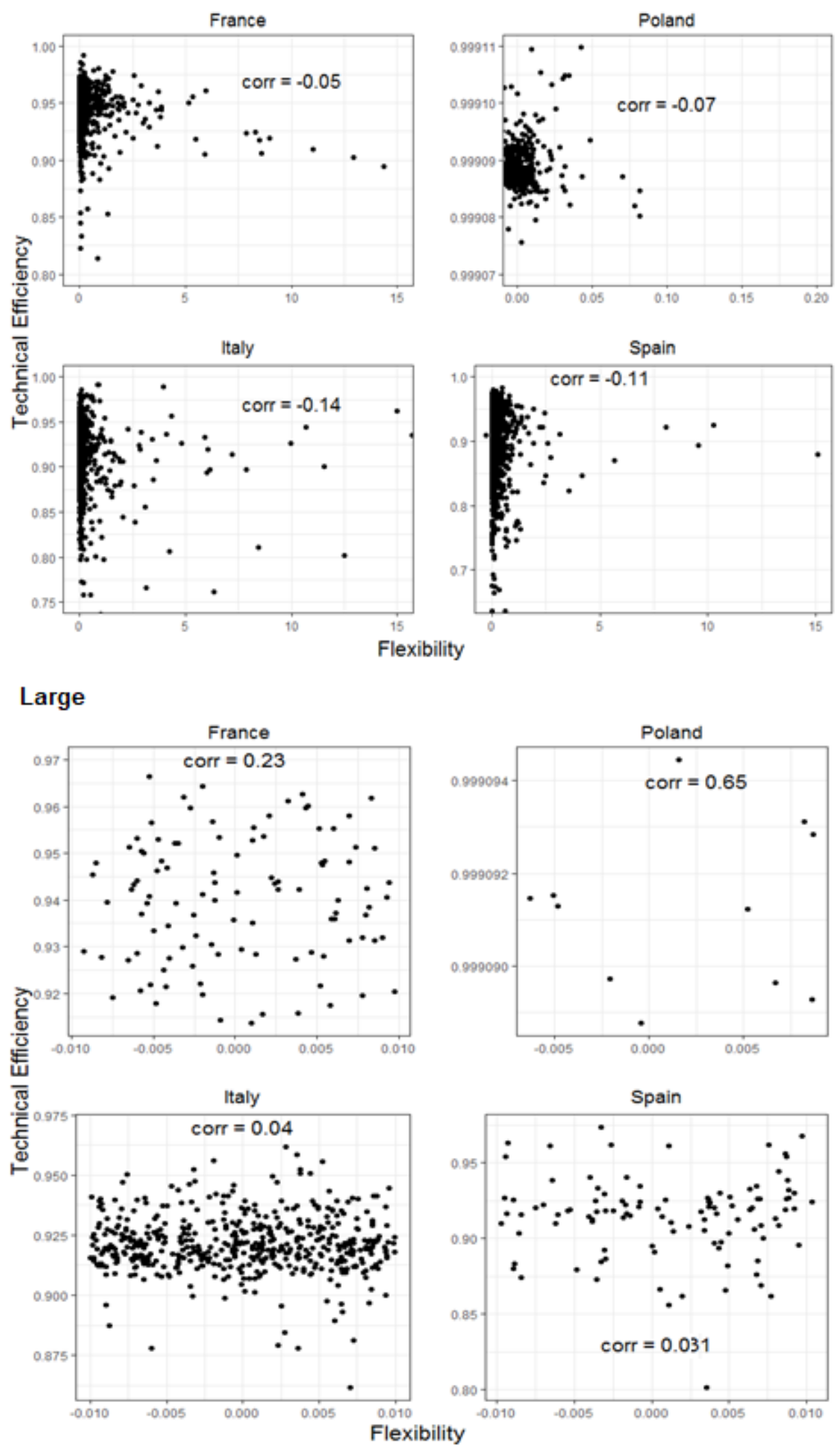

Figure A2. Relationships between flexibility and efficiency by size class Notes: corr $=$ Spearman correlation coefficient; Small: $<€ 20$ mio. in TA. Large $>€ 20$ mio. in TA 


\section{References}

Aigner, D.J., Lovell, C.A.K., and Schmidt, P. (1977). Formulation and estimation of stochastic frontier production function models. Journal of Econometrics 101: 219-255.

Aigner, K. and Weiss, C.R. (1998). Does it pay to be flexible? Review of Industrial Organization 13: 543-556.

Ali, J. (2007). Productivity and Efficiency in Indian Meat Processing Industry: A DEA Approach. Indian Journal of Agricultural Economics 62(4): 637-648.

AMI (2017). Markt Bilanz Milch 2017. Bonn, Germany: Agrarmarkt Informations-Gesellschaft (AMI)

Arellano, M. and Bond, S. (1991). Some tests of specification for panel data: Monte Carlo evidence and an application to employment equations. Review of Economic Studies 58(2): 277-297.

Baker, M., Powell, D., and Smith, T.A. (2016). QREGPD: Stata module to perform Quantile Regression for Panel Data IDEAS RePEc. https://ideas.repec.org/c/boc/bocode/s458157.html

Baltagi, B. H. (2008). Econometric Analysis of Panel Data. Chichester, UK: John Wiley \& Sons.

Banterle, A., Alessia, C., Carraresi, L., and Stranieri, S. (2013). Food SMEs Face Increasing Competition in the EU Market: Marketing Management Capability Is a Tool for Becoming a Price Maker. Agribusiness 30: 113-131.

Battese, G.E., and Coelli, T.J. (1995). A model for technical inefficiency effects in a stochastic frontier production function for panel data. Empirical Economics 20: 325-332.

Becker, S.O. and Ichino, A. (2002). Estimation of average treatment effects based on propensity scores, The Stata Journal 2(4): 258-377.

Bellemare, M.F., Masaki, T. and Pepinsky, T.B. (2017). Lagged explanatory variables and the estimation of causal effect. The Journal of Politics 79(3): 949-963.

Belotti, F., Daidome, S., Ilardi, G., and Atella, V. (2013). Stochastic frontier analysis using Stata. The Stata Journal 13(4): 719-758.

Berman, S.L., Wicks, A.C., Kotha, S. and Jones, T.M. (1999). Does Stakeholder Orientation Matter? The Relationship between Stakeholder Management Models and Firm Financial Performance. The Academy of Management Journal 42(5): 488-506.

Betz, T., Cook, S.J. and Hollenbach, F.M. (2018). On the use and abuse of spatial instruments. Political Analysis 26(4): 474-479.

Billor, N., A. S. Hadi, and Velleman, P.F. (2000). BACON: Blocked adaptive computationally efficient outlier nominators. Computational Statistics \& Data Analysis 34: 279-298.

Bokusheva, R. and Čechura, L. (2017). Evaluating dynamics, sources and drivers of productivity growth at the farm level. OECD Food, Agriculture and Fisheries Papers, No. 106. Paris: OECD Publishing.

Boulanger, P., Dudu, H., Ferrari, E., and Philippidis, G. (2016). Russian Roulette at the Trade Table: A Specific Factors CGE Analysis of an Agri-food Import Ban. Journal of Agricultural Economics 67(2), 272-291.

Buzzell, R.D. and Gale, B.T. (1987). The PIMS principles: Linking strategy to performance. New York: Free Press.

BvD (2007). AMADEUS Internet User Guide. Frankfurt, Germany: Bureau van Dijk Electronic Publishing. 
Caliendo, M. and Kopeining, S. (2005). Some Practical Guidance for the Implementation of Propensity Score Matching. IZA Discussion Paper No. 1588. IZA Discussion Paper Series.

Cassandro, M. (2003). Status of Milk Production and Market in Italy. Agriculturae Conspectus Scientificus 68(2): 65-69.

Chaddad, F.R, and Mondelli, M.P. (2013). Sources of Firm Performance Differences in the US Food Economy, Journal of Agricultural Economics 64(2): 382-404.

Chavas, J.P., Chambers, R.G., and Pope, R.D. (2010). Production economics and farm management: a century of contributions. American Journal of Agricultural Economics 92: 356-375

Coelli, T., Perelman, S. (2000). Technical efficiency of European railways: A distance function approach. Applied Economics 32(15): 1967-1976.

Collins, R.A. (1985). Expected utility, debt-equity structure, and risk balancing. American Journal of Agricultural Economics, 67(3), 627-629.

Cook, M.L. (1995). The Future of U.S: Agricultural Cooperatives: A Neo-Institutional Approach. American Journal of Agricultural Economics 77(5): 1153-1159.

Cragg, J.G. and Donald, S.G. (1993). Testing identifiability and specification in instrumental variable models. Econometric Theory 9: 222-240.

Das, B.J., Chappell, W.F., and Shughart, W.F. (1993). Demand fluctuations and firm heterogeneity. The Journal of Industrial Economics 41(1): 51-60.

De Toni, A., and Tonchia, S. (1998). Manufacturing flexibility: A literature review. International Journal of Production Research 36(6): 1587-1617

De Toni, A., and Tonchia, S. (2005). Definitions and linkages between operational and strategic flexibilities. Omega 33: 525-540.

Diewert, W.E. (1971). An application of the Shepard duality theorem: A generalized Leontief production function. The Journal of Political Economy 79(3): 481-507.

Diewert, W.E. and Wales, T.J. (1987). Flexible Functional Forms and Global Curvature Conditions. Econometrica, 55(1): 43-68.

Dimara, E., Skuras, D., Tsekouras, K., and Tzelepis, D. (2008). Productive efficiency and firm exit in the food sector. Food Policy 33: 185-196.

Dries, L. and Swinnen, J.F.M. (2004). Foreign Direct Investment, Vertical Integration, and Local Suppliers: Evidence from the Polish Dairy Sector. World Development 32(9): 15251544.

Eaton, B.C. and Schmitt, N. (1994). Flexible Manufacturing and Market Structure. The American Economic Review 84(4): 875-888.

Eisenhardt, K.M., Furr, N.R., and Bingham, C.B. (2010). Microfoundations of Performance: Balancing Efficiency and Flexibility in Dynamic Environments. Organization Science 21(6): 1263-1273.

European Commission (2005). The New SME Definition. Enterprise and Industry Publications. Luxembourg: European Commission.

European Commission (2013). Thresholds defining micro, small and medium-sized companies. Luxembourg: European Commission.

Eurostat (2012). Handbook on industrial producer price indices (PPI). Luxembourg: European Commission

Eurostat (2017) Annual Detailed Enterprise Statistics on Manufacturing Subsections DA-DE and Total Manufacturing. Luxembourg: European Commission. http://epp.eurostat.ec.europa.eu. Accessed 30 January 2017. 
Eurostat (2017a) Producer prices in industry, domestic market - monthly data. Luxembourg: European Commission. http://epp.eurostat.ec.europa.eu. Accessed 28 February 2017.

Eurostat (2017b) Harmonized index of consumer prices. Luxembourg: European Commission. http://epp.eurostat.ec.europa.eu. Accessed 28 February 2017

Färe, R., Grosskopf, S., Knox Lovell, C.A. and Yaisawarng, S. (1993). Derivation of Shadow Prices for Undesirable Outputs: A Distance Function Approach. The Review of Economics and Statistics 75(2): 374-380.

Färe, R., and Primont, D.A. (1995). Multi-output production and duality. Theory and applications. Boston: Kluwer Acad. Publ.

Fiegenbaum, A., and Karnani, A. (1991). Output flexibility — a competitive advantage for small firms. Strategic Management Journal 12(2): 101-114.

FoodDrink Europe (2011) Data and Trends of the European Food and Drink Industry 2011. Luxembourg: European Commission.

Ghemawat, P. and Ricart Costa, J.E. (1993). The Organizational Tension between Static and Dynamic Efficiency. Strategic Management Journal 14(52): 59-73.

Giles, J. (2015). Change in the EU Dairy Sector Post Quota: More Milk, More Exports and a Changing Farmer Profile. EuroChoices 14(3), 20-25.

Goddard, J.A., Tavakoli, M., and Wilson, J.O.S. (2005). Determinants of profitability in European manufacturing and services: evidence from a dynamic panel model. Applied Financial Economics 15(18): 1269-1282.

Greene, W. (2005a). Reconsidering heterogeneity in panel data estimators of the stochastic frontier model. Journal of Econometrics 126: 269-303.

Greene, W (2005b). Fixed and random effects in stochastic frontier models. Journal of Productivity Analysis 23: 7-32.

Gschwandtner, A. and Hirsch, S. (2017). What Drives Firm Profitability? A Comparison of the US and EU Food Processing Industry. The Manchester School. doi: 10.1111/manc.12201.

Gupta, Y.P. and Somers, T.M. (1992). The measurement of manufacturing flexibility. European Journal of Operational Research 60: 166-182.

Hemme, T., Ndambi, A. and Schröer-Merker, E. (2013). Overview on milk prices and production costs worldwide. IFCN report 2013, available at: http://www.milkproduction.com/Global/PDFs/WDS-\%20IFCN\%20Dairy\%20Report\%202 013.pdf, last: Oct 2017.

Hendrikse, G.W.J. and Veerman, C.P. (2001). Marketing Cooperatives and financial structure: a transaction costs economic analysis. Agricultural Economics 26: 205-216.

Hill, H. and Kalirajan (1993). Small enterprise and firm-level technical efficiency in the Indonesian garment industry. Applied Economics 25(9): 1137-1144.

Hirsch, S. (2014). Abnormal Profits and Profit Persistence: Evidence from the European Food Industry. Bonn, Germany: Dissertation, University of Bonn.

Hirsch, S. (2018). Successful in the long run: A meta-regression analysis of persistent firm profits. Journal of Economic Surveys 32(1): 23-49.

Hirsch, S. and Gschwandtner, A. (2013). Profit persistence in the food industry: evidence from five European countries. European Review of Agricultural Economics 40(5): 741-759.

Hirsch, S. and Hartmann, M. (2014). Persistence of firm-level profitability in the European dairy processing industry. Agricultural Economics 45(S1): 53-63

Ilbery, B. and Kneafsey, M. (1999). Niche markets and regional speciality food products in Europe: towards a research agenda. Environment and Planning 31: 2207-2222. 
Jain, A., Jain, P.K., Chan, F.T.S., and Singh, S. (2013). A review on manufacturing flexibility. International Journal of Production Research 51(19): 5946-5970.

Jorda, O. (2005). Estimation and inference of impulse responses by local projections. American Economic Review 95(1): 161-182.

Jovanovic, B. (1982). Selection and the Evolution of Industries. Econometrica 50(3): 649-670

Kapelko, M., Oude Lansink, A., and Stefanou, S. (2016). Assessing the Impact of Changing Economic Environment on Productivity Growth: The Case of the Spanish Dairy Processing Industry. Journal of Food Products Marketing 23(4): 384-397.

Keane, M. and Connor, D.O. (2009). Price volatility in the EU dairy industry: Causes, consequences, and coping mechanisms. Report Prepared for the European Dairy Association October 2009, Department of Agriculture, Food and the Marine, Dublin, Ireland.

Kortmann, S., Gelhard, C., Zimmermann, C., and Piller, F.T. (2014). Linking strategic flexibility and operational efficiency: The mediating role of ambidextrous operational capabilities. Journal of Operations Management 32: 475-490.

Kumbhakar, S.C., Asche, F., and Tveteras, R. (2013). Estimation and decomposition of inefficiency when producers maximize return to the outlay: an application to Norwegian fishing travelers. Journal of Productivity Analysis 40: 307-321.

Kumbhakar, S.C., Wang, H.-J., Horncastle, A.P. (2015). A Practioner`s Guide to Stochastic Frontier Analysis Using Stata. New York: Cambridge University Press.

Lienhardt, J. (2004). The food industry in Europe. Statistics in focus 39/2004. Luxembourg: European Communities.

Loderer, C., Waelchli, U. (2010). Firm age and performance. Working paper: University of Bern.

Lundvall, K. and Battese, G.E. (2000). Firm size, age and efficiency: Evidence from Kenyan manufacturing firms. The Journal of Development Studies 36(3): 146-163.

Majumdar, S. K. (1997). The impact of size and age on firm-level performance: some evidence from India. Review of Industrial Organization 12(2): 231-241.

Merschmann, U. and Thonemann, U.W. (2011). Supply chain flexibility, uncertainty and firm performance: An empirical analysis of German manufacturing firms. International Journal of Production Economics 130: 43-53.

Mills, D.E. (1984). Demand Fluctuations and Endogenous Firm Flexibility. The Journal of Industrial Economics 33(1): 55-71.

Mills, D.E. (1985). Flexibility and firm diversity with demand fluctuations. International Journal of Industrial Organization 4: 302-215.

Mills, D.E. and Schumann, L. (1985). Industry structure with fluctuating demand. American Economic Review 75(4): 758-767.

Mishra, A.K. and Lence, S. H. (2005). Risk management by farmers, agribusinesses, and lenders. Agricultural Finance Review 65(2): 131-148.

Morey, E.R. (1986). An Introduction to Checking, Testing, and Imposing Curvature Properties: The True Function and the Estimated Function. The Canadian Journal of Economics 19(2): 207-235.

Morrison Paul, C., Nehring, R., Banker, D., and Somwaru, A. (2004). Scale Economies and Efficiency in U.S. Agriculture: Are Traditional Farms History? Journal of Productivity Analysis 22: 185-205

Moschini, G., Menapace, L., and Pick, D. (2008). Geographical indications and the competitive provision of quality in agricultural markets. American Journal of Agricultural Economics, 90(3), 794-812. 
Mueller, D.C. (1990). Dynamics of Company Profits: An International Comparison, Cambridge, UK, Cambridge University Press.

Nemoto, J., and Furumatsu, N. (2014). Scale and scope economies of Japanese private universities revisited with an input distance function approach. Journal of Productivity Analysis, 41: 213-226.

Nilsson, J. (2001). Organisational principles for co-operative firms. Scandinavian Journal of Management 17(3): 329-356.

Novkovic, S. (2008). Defining the co-operative difference. The Journal of Socio-Economics 37: 2168-2177.

O'Donnell, C.J. and Coelli, T.J. (2005). A Bayesian approach to imposing curvature on distance functions. Journal of Econometrics 126: 493-523.

Olsen, N.V., Elvekrok, I., and Nilsen, E.R. (2012). Drivers of food SMEs network success: 101 tales from Norway. Trends in Food Science and Technology 26: 120-128.

Paul, C.J.M., Johnston, W.E. and Frengley, G.A.G. (2000). Efficiency in New Zealand Sheep and Beef Farming: The Impacts of Regulatory Reform. Review of Economics and Statistics, 82(2): 325-337.

Powell, D. (2016). Quantile Regression with Nonadditive Fixed Effects. RAND Corporation. https://works.bepress.com/david_powell/1/.

Reed, W. R. (2015). On the Practice of Lagging Variables to Avoid Simultaneity. Oxford Bulletin of Economics And Statistics, 77(6): 897-905.

Renner, S. (2014). Flexibilität von Unternehmen. Eine theoretische und empirische Analyse. Studies on the Agricultural and Food Sector in Transition Economies, Leibniz Institute of Agricultural Development in Transition Economies IAMO Volume 75

Renner, S, Glauben, T, and Hockmann, H. (2014). Measurement and decomposition of flexibility of multi-output firms. European Review of Agricultural Economics 41: 745-773.

Renner, S., Glauben, T., Hockmann, H. and Ouellette, P. (2015). Primal and dual multi-output flexibility measures. Journal of Productivity Analysis 44(2): 127-136.

Röller, L.-H. and Tombak, M.M. (1993). Competition and Investment in Flexible Technologies. Management Science 39(1): 107-114.

Roodman, D. (2009). How to do xtabond2: An introduction to difference and system GMM in Stata. The Stata Journal 9(1): 86-136.

Serra, T. and Goodwin, B.K. (2003). Price transmission and asymmetric adjustment in the Spanish dairy sector. Applied Economics 35(18): 1889-1899.

Sethi, A.K. and Sethi, S.P. (1990). Flexibility in Manufacturing: A Survey. The International Journal of Flexible Manufacturing Systems 2: 289-328.

Shaw, D.S., Shaw, A.C., Shaw, S.S., and Leigh, R. (1999). The single European market and SMEs: a comparison of its effects in the food and clothing sectors in the UK and Portugal. Regional Studies 33(1): 51-62.

Shevlyakov, G. and Smirnov, P. (2011). Robust Estimation of the Correlation Coefficient: An Attempt of Survey. Austrian Journal of Statistics 40: 147-156.

Sineiro, F., and I. Vázquez. 2014. The Spanish dairy sector. 30th European Holstein and Red Holstein Conference, Spain. http://www.euholsteins.com/info/ documents/1SineiroVazquez.pdf, last: 19.10.2017

Soboh, R.A.M.E., Oude Lansink, A.O., and van Dijk, G. (2011). Distinguishing Dairy Cooperatives From Investor-Owned Firms in Europe Using Financial Indicators. Agribusiness 27(1): 34-46. 
Soboh, R., Oude Lansink, A.O., and van Dijk, G. (2012). Efficiency of Cooperatives and Investor Owned Firms Revisited. Journal of Agricultural Economics 63(1): 142-157.

Soboh, R.A.M.E., Lansink, A.O., Giesen, G., and van Dijk, G. (2009). Performance Measurement of the Agricultural Marketing Cooperatives: The Gap between Theory and Practice. Review of Agricultural Economics 31, 446-469.

Soregaroli, C., Sckokai, P., Moro, D. (2011). Agricultural policy modelling under imperfect competition. Journal of Policy Modelling 33: 195-212.

Stigler, G.J. (1939). Production and distribution in the short run. The Journal of Political Economy 47(3): 305-327.

Vokurka, R.J. and O'Leary-Kelly, S.W. (2000). A review of empirical research on manufacturing flexibility. Journal of Operations Management 18: 485-501.

von Ungern-Sternberg, T. (1990). The flexibility to switch between different products. Economica 57: 355-369.

Weber, S. (2010). bacon: An effective way to detect outliers in multivariate data using Stata (and Mata). The Stata Journal 10(3): 331-338.

Weiss, C.R. (2001). On flexibility. Journal of Economic Behavior and Organization 46: 347356.

Wijnands, J.H.M., van der Meulen, B.M.J. and Poppe, K.J. (2007). Competitiveness of the European Food Industry: An Economic and Legal Assessment 2007. Luxembourg: European Commission.

Wilkin, J., Milczarek, D., Falkowski, J., and Malak-Rawlikowska, A. (2006). The dairy sector in Poland. Regoverning Markets, Agrifood Sector Series. London: IIED.

Wooldridge, J.M. (2006). Introductory Econometrics. Mason, US: Thomson Higher Education.

Zeller, M. and Robison, L.J. (1992). Flexibility and risk in the firm. European Review of Agricultural Economics 19: 473-484.

Zellner, A. (1963). Estimators for Seemingly Unrelated Regression Equations: Some Exact Finite Sample Results. Journal of the American Statistical Association 58(304): 977-992.

Zimmermann, K.F. (1995). Flexibility in the face of demand fluctuations: Employment, capacity utilization, and industry structure. International Journal of Industrial Organization 13: 179-193. 